\title{
Kiprah Aktor Warganet melalui Media Sosial dalam Pemasaran Digital: Studi Kasus pada \#HondaBeAT
}

\author{
Bambang Arianto \\ Akuntansi, STISIP Banten Raya, Indonesia \\ Andriya Risdwiyanto \\ Manajemen, Universitas Proklamasi 45 Yogyakarta, Indonesia \\ Korespondensi penulis: ariantobambang2020@gmail.com
}

\begin{abstract}
This study aims to determine the role of netizen actors on social media in the digital marketing of a product brand, like \#HondaBeAT. Nowadays, the use of social media to exchange information is increasing for the dissemination of messages and other contents. In the digital marketing ecosystem, social media plays an important role in introducing products, enhancing a positive image, and building relationships with customers. The use of social media platforms, such as Twitter and Instagram, has attracted the attention of the younger generation, especially the millennial generation $(Y)$ and the postmillennial generation (Z). The level of effectiveness of digital marketing is also influenced and determined by the progress of netizen actors, such as followers, influencers, and buzzers. Their role is increasingly important to convey information more effectively through various product and service brand content on various social media platforms. This study uses a qualitative approach to analyze data from social media conversations on Twitter and Instagram within a certain period of time with the help of the Drone Emprit Academic (DEA) application. This research reveals the progress of netizen actors on the company's official accounts of Twitter and Instagram as a basic understanding for designing and compiling digital marketing strategies using product brand hashtags. This study also found that the netizen actors studied had their respective roles in strengthening the delivery of messages and content on social media.
\end{abstract}

Keywords: Digital marketing; Drone Emprit Academic (DEA); Hashtags; Netizen actors; Social media.

\begin{abstract}
Abstrak. Penelitian ini bertujuan untuk mengetahui kiprah aktor warganet di media sosial dalam pemasaran digital sebuah merek produk melalui \#HondaBeAT. Dewasa ini, pemanfaatan media sosial sebagai sarana pertukaran informasi semakin meningkat untuk penyebaran pesan maupun konten lainnya. Dalam ekosistem pemasaran digital, media sosial berperan penting untuk memperkenalkan produk, meningkatkan citra positif, hingga membangun relasi dengan konsumennya. Pemanfaatan platform media sosial, seperti
\end{abstract}


Twitter dan Instagram sangat menarik perhatian kalangan generasi usia muda, khususnya generasi milenial (Y) dan generasi pasca milenial (Z). Tingkat keefektifan pemasaran digital juga dipengaruhi dan ditentukan oleh kiprah aktor warganet, seperti followers, influencer, dan buzzer. Kiprah mereka semakin penting untuk menyampaikan informasi secara lebih efektif melalui berbagai konten merek produk dan jasa di berbagai platform media sosial. Penelitian ini menggunakan pendekatan kualitatif untuk menganalisis data hasil percakapan media sosial di Twitter dan Instagram dalam periode waktu tertentu dengan bantuan aplikasi Drone Emprit Academic (DEA). Penelitian ini mengungkapkan kiprah para aktor warganet di Twitter dan Instagram resmi perusahaan sebagai pemahaman dasar untuk mendisain dan menyusun strategi pemasaran digital menggunakan tagar merek produk. Penelitian ini juga menemukan bahwa aktor warganet yang diteliti memiliki peran mereka masing-masing dalam penguatan penyampaian pesan dan konten di media sosial.

Kata Kunci: Aktor warganet; Drone Emprit Academic (DEA); Media sosial; Pemasaran Digital; Tagar.

\section{Article Info:}

Received: January 26, 2020

Accepted: May 16, 2021

Available online: August 2, 2021

DOI: http://dx.doi.org/10.30588/jmp.v11i1.636

\section{LATAR BELAKANG}

Perkembangan teknologi informasi membuat semua aspek bisnis banyak dipengaruhi oleh proses digitalisasi. Pelaku bisnis saat ini merespon dengan memanfaatkan teknologi digital untuk segala aktifitas pemasaran berbagai produk dan jasa. Hal itulah yang membuat peran pemasaran digital semakin dibutuhkan. Bahkan, model pemasaran ini kemudian dikenal sebagai era kebangkitan pemasaran interaktif (Stone \& Woodcock, 2014). Salah satu saluran pemasaran digital yakni dengan pemanfaatan media sosial yang kemudian telah banyak mempengaruhi semua aspek kehidupan bisnis di berbagai tingkatan masyarakat dalam dekade terakhir ini.

Dalam konteks bisnis digital, media sosial telah menjadi salah satu kunci kesuksesan dalam upaya memperkuat merek produk dan jasa, baik untuk pelaku usaha perorangan maupun perusahaan dalam skala lebih besar. Dengan demikian, baik buruknya upaya pelaku usaha untuk memperkuat merek produknya sangat tergantung dari pengelolaan media sosialnya. Salah satu upaya tersebut adalah menciptakan hubungan baik antara perusahaan dan konsumen secara intensif, personal, dan setara. Interaksi tersebut dapat melahirkan banyak masukan dan kritik demi kemajuan produk dan jasa yang dipasarkan. Dengan demikian, pemasaran melalui media sosial merupakan syarat mutlak untuk meraih kesuksesan dalam bisnis digital. Selain itu, beberapa penelitian sebelumnya menemukan bahwa strategi pemasaran digital telah memastikan pemasaran digital sangat efektif mempengaruhi perilaku kalangan milenial (Smith, 2011).

Dalam konteks pemasaran digital, tidak hanya menggunakan internet sebagai saluran pemasaran, akan tetapi berupaya memanfaatkan semua saluran termasuk media sosial. 
Bahkan, dalam konteks pemasaran digital, pemanfaatan media sosial menjadi salah satu hal utama untuk saluran informasi bisnis. Dengan kata lain, pemilihan media sosial sangat menentukan keberhasilan pemasaran digital. Pengguna internet dan akun media sosial mengalami pertumbuhan yang cukup signifikan di era digital sekarang ini (Setiawati, Fitriawati, Retnasary, \& Yelifa, 2019). Sampai saat ini, beberapa platform media sosial publik semakin banyak dimanfaatkan sebagai saluran bisnis maupun pemasaran produk perusahaan, seperti Facebook (FB), Instagram (IG), Twitter, dan Youtube, serta salah satu media sosial privat, yakni Whatsapp atau WA (Gityandraputra, 2020). Dalam kegiatan bisnis digital, penggunaan satu media sosial saja dirasakan kurang efektif, karena setiap platform media sosial tersebut memiliki segmentasi dan pengguna yang berbeda.

Jejaring media sosial dapat dimanfaatkan untuk tujuan pemasaran produk sebagai bagian dari pemasaran digital perusahaan (Susilo, 2018). Kalangan usia muda di Indonesia menganggap Facebook (FB) sebagai platform yang lebih tepat bagi generasi tua, sedangkan Instagram (IG) lebih banyak digemari oleh generasi milenial, karena IG dapat menampilkan variasi konten berupa video dan gambar atau foto yang banyak disukai oleh generasi milenial (CNBC Indonesia, 2018). Bahkan, pengguna IG di Indonesia didominasi oleh mereka dari golongan usia produktif, yakni mereka yang berusia dalam rentang 18-34 tahun yang mencapai lebih dari 80\% (Rizal, 2019).

Dari 25 juta orang pengguna media sosial di Indonesia, 36\%-38\% di antaranya adalah mereka yang berusia antara 18-24 tahun, sedangkan 31\%-33\% berusia 25-34 tahun (Iman, 2020). Selain itu, data demografi pengguna media sosial di Indonesia yang dirilis oleh Itworks.id (2019) menyatakan bahwa mayoritas pengguna Twitter berusia 16-24 tahun sebanyak 42\%, berusia 23-34 tahun sebanyak 36\%, berusia 35-44 tahun sebanyak 18\%, berusia 45-54 tahun sebanyak 3\%, dan berusia 55-64 tahun sebanyak 1\%. Di sisi lain, media Youtube lebih menekankan pada tampilan video dokumenter dan aktualisasi diri kalangan milenial (Arianto, 2020b), sedangkan Whatsapp (WA) semakin banyak digunakan oleh mayoritas masyarakat pengguna gadget, karena WA langsung terhubung dengan telepon seluler sebagai alat komunikasi yang populer di masyarakat.

Selain pemilihan saluran atau platform media sosial, pemilihan konten juga menjadi faktor penting untuk memperkuat strategi pemasaran digital. Dengan konten yang tidak tepat, platform media sosial apa pun yang dipilih tidak akan memiliki pengaruh yang signifikan. Sebaliknya, konten kreatif dan menarik dapat membuat produk dan jasa yang dipasarkan mendapatkan respon oleh publik, sehingga pengaruhnya lebih dapat diterima pasar. Saat ini, konten gambar dan video merupakan konten yang paling digemari oleh konsumen (Gityandraputra, 2020). Namun, konten berupa teks berpengaruh penting untuk pencarian kata kunci (keywords) yang dapat mengarahkan pada meningkatnya kunjungan website dan terjadinya penjualan produk (Sofyan, Ferdianto, Rahmawati, \& Aldi, 2019).

Konten berupa teks lebih banyak dimanfaatkan oleh para blogger untuk menuliskan pengalamannya atas suatu produk agar produk tersebut mendapatkan citra positif. Dengan demikian, copywriting (penulisan teks) yang menarik, informatif, dan kreatif sangat menentukan warganet lainnya untuk membacanya (Arianto, 2020b). Dengan kata lain, keahlian menulis sangat menentukan karena dapat membantu pembuatan konten dengan copywriting yang menarik pula. Selain konten, pemasaran digital yang menggunakan media sosial juga 
melihat posisi penting para aktor warganet yang terdiri atas buzzer, influencer, dan follower. Ketiga aktor inilah yang sering dijumpai dalam khazanah masyarakat digital atau warganet.

Buzzer adalah salah satu aktor warganet pemilik akun media sosial yang setiap saat menyebarluaskan, mengkampanyekan, dan mendengungkan pesan atau konten secara terus menerus kepada warganet lainnya dengan tujuan memperkuat pesan atau konten tersebut (Arianto, 2020b; Akmal \& Irwansyah, 2020), sedangkan Follower adalah pemilik akun media sosial yang mengikuti akun-akun media sosial pihak lain. Akun media sosial yang banyak diikuti atau memiliki kemampuan mempengaruhi akun-akun lainnya disebut sebagai influencer (Hanindharputri \& Putra, 2019). Para follower memiliki karakter yang selalu mengikuti perilaku influencer yang diikuti. Biasanya, para follower menggunakan media sosial hanya untuk mengisi waktu luang, sehingga konten yang ada dalam follower's timelines rata-rata merupakan postingan ulang dari akun influencer atau buzzer yang mereka ikuti.

Tindakan yang biasa mereka lakukan adalah repost, retweet, reshare, memberikan komen atau komentar, hingga menyukai (like) pesan tersebut. Influencer merupakan pemilik akun media sosial yang memiliki pengaruh kuat terhadap banyak followernya, sehingga mereka dapat mendorong followernya untuk berbuat sesuai nalar atau kehendaknya (Amalina, 2016; Arianto, 2020a). Selain itu, follower juga dapat ditemui pada akunakun yang ingin mencari keuntungan ekonomi, seperti kuis berhadiah (give away), sehingga follower seperti itu seringkali membuat banyak akun hanya untuk mengikuti akun-akun influencer dan buzzer agar mereka dapat mengikuti kuis berhadiah (Fahmi, 2019a; Ayuningtyas \& Lailiyah, 2019).

Ketiga aktor meliputi buzzer, influencer, maupun follower memiliki pola perilaku masing-masing yang dapat mempengaruhi pandangan warganet lainnya. Para aktor ini cukup memahami karakter masyarakat digital yang berkembang sesuai klaster mereka. Misalnya, seorang influencer di bidang fotografi memiliki jejaring para penyuka foto, pelaku fotografi, dan semacamnya. Oleh karena itu, sebuah merek produk dan jasa akan mencari para aktor yang mampu berperan untuk memperkuat konten mereka sesuai segmentasi produk tersebut. Produk fotografi akan mencari influencer dan buzzer yang mengerti, memahami, atau menekuni dunia fotografi. Banyak perusahaan di Indonesia menggunakan peran dan jasa para aktor warganet (Kontan.co.id, 2013). Perusahaan menggunakan peran buzzer di media sosial, karena mereka memiliki jumlah pengikut (follower) yang cukup banyak. Penggunaan buzzer oleh perusahaan bertujuan untuk membantu menginformasikan acara-acara atau events yang diselenggarakan oleh perusahaan berkaitan dengan produknya. Selain itu, hubungan buzzer dan follower lebih bersifat personal, sehingga pesan dari buzzer akan lebih efektif tersampaikan kepada follower. Pesan-pesan pemasaran berperan penting dalam pemasaran merek dan produk perusahaan, karena dampak pencitraan yang mampu dihasilkannya (Setiawati et al., 2019).

Penelitian ini menganalisis perilaku digital (digital behavior) para aktor warganet, yaitu buzzer, influencer, dan follower di platform media sosial Twitter dan Instagram yang banyak digunakan dan disukai oleh kalangan muda usia di Indonesia. Twitter merupakan media sosial yang digunakan untuk memasarkan produk dengan jumlah pengguna usia 
muda mencapai lebih dari 80\% (Rizal, 2019), sedangkan Instagram merupakan media sosial yang paling banyak digunakan perusahaan untuk memasarkan produknya (Siagian, Martiwi, \& Indra, 2020). Semakin tingginya intensitas penggunaan media sosial dan perilaku aktor warganet yang dapat menjadi salah satu saluran pemasaran digital perusahaan, pemikiran yang mendasari penelitian ini adalah bagaimana kiprah aktor warganet di media sosial mereka untuk memperkuat konten pemasaran digital sebuah merek produk.

Dari latar belakang tersebut, tujuan penelitian ini adalah untuk mengetahui kiprah para aktor warganet secara digital di media sosial mereka untuk memperkuat konten informasi merek produk, yaitu \#HondaBeat dalam ekosistem pemasaran digital perusahaan tersebut. Penelitian ini memiliki arti penting bagi perusahaan untuk memahami intensitas kepentingan buzzer, influencer, dan follower dalam perilaku digital mereka sebagai alternatif saluran komunikasi pemasaran digital mereka. Selain itu, temuan penelitian ini juga memberikan wawasan baru bagi kalangan akademisi untuk mengembangkan pemahaman lebih jauh terhadap strategi pemasaran digital perusahaan dengan melibatkan aktor-aktor warganet sebagai agen pemasaran perusahaan.

\section{KAJIAN TEORITIS}

\section{Pemasaran Digital}

Pemasaran digital (digital marketing) mengacu pada konsep dasar pemasaran. Pemasaran merupakan proses mengelola hubungan pelanggan yang memberikan keuntungan kedua belah pihak antara pemasar dan konsumennya (Kotler \& Armstrong, 2012). Tujuan utama pemasaran digital adalah upaya untuk menarik pelanggan baru dengan menjanjikan nilai superior dan membuat hubungan antara pemasar dan pelanggan dalam berinteraksi semakin intensif dilakukan melalui penggunaan media sosial (Handajani, Akram, Furkan, \& Rifa'i, 2019; Yasmin, Tasneem, \& Fatema, 2015). Dalam bisnis digital, pemasaran online adalah aktifitas pemasaran yang dilakukan melalui sistem online secara interaktif yang menghubungkan antara konsumen dan penjual secara elektronik (Kotler \& Armstrong, 2012; Karinov.co.id, 2018). Banyak perusahaan yang telah memanfaatkan pemasaran digital dalam strategi pemasaran produknya, tetapi banyak pula yang masih belum mengoptimalkan penggunaan media sosial dengan baik karena berbagai keterbatasan yang mereka miliki (Rony \& Panuju, 2018; Pelsmacker, Tilburg, \& Holthof, 2018).

Media digital merupakan sarana promosi bisnis untuk memasarkan produk dan jasa yang semakin banyak digunakan, karena media sosial terkoneksi jejaring internet yang dapat memberikan dukungan lebih jauh bagi keberhasilan pemasaran produk perusahaan dengan cara yang lebih mudah, lebih cepat, lebih murah, dan tanpa memerlukan tambahan investasi yang besar (Aliami, Hakimah, \& Fauji, 2018). Sistem pemasaran secara digital menggunakan internet merupakan bagian dari perkembangan teknologi informasi yang memungkinkan terjadinya pemasaran secara langsung berbasis internet, sehingga hubungan pemasar dan konsumen dapat dilakukan secara langsung, real time, dan interaktif untuk memasarkan produk perusahaan (Asriani, 2011; Siagian et al., 2020). 
Kotler (dalam Andriyanto \& Haryanto, 2010; Rahayu, 2018) menyebutkan bahwa penerapan digital marketing memberikan beberapa manfaat. Pertama, sistem pemasaran digital dapat dijalankan oleh perusahaan kecil maupun besar. Kedua, aktifitas iklan secara online tidak memiliki batas nyata dalam ruang dan waktu dibandingkan dengan media offline. Ketiga, akses dan pencarian informasi dapat dilakukan lebih cepat. Keempat, situsnya dapat dikunjungi oleh siapa pun, di mana pun, dan kapan pun di seluruh dunia (world wide). Kelima, aktifitas belanja atau transaksi dapat dilakukan secara lebih cepat dan akurat.

\section{Media Sosial}

Dewasa ini, media sosial telah menjadi salah satu saluran penyampaian informasi yang sangat berpengaruh di semua sektor kehidupan publik. Media sosial merupakan sarana yang memungkinkan interaksi antarmanusia secara online tanpa batasan ruang dan waktu (Maulana \& Salsabila, 2020). Dengan demikian, media sosial adalah sebuah kelompok aplikasi berbasis internet yang dibangun atas dasar ideologi dan teknologi web 2.0 dan memungkinkan penciptaan dan pertukaran konten sesuai pengguna masing-masing (user generated content). Selanjutnya, mereka juga menyatakan bahwa media sosial dapat diartikan pula sebagai sebuah media berbasis kecanggihan teknologi yang diklasifikasikan dalam berbagai bentuk, seperti majalah, forum internet, weblog, blog sosial, microblogging, wikipedia, foto atau gambar, video peringkat, dan bookmark sosial (Kaplan \& Haenlein, 2010).

Dalam perkembangannya, Castells (2007) menyebutkan bahwa media sosial yang dikenal dalam masyarakat jejaring (network) saat ini memiliki empat bentuk kekuatan. Pertama, kekuatan jaringan yang menjadi kekuatan aktor dan organisasi sebagai komponen inti dalam masyarakat jejaring global. Kedua, kekuatan jaringan yang dihasilkan mampu mengkoordinasikan berbagai interaksi sosial dalam jejaring. Ketiga, kekuatan aktor sosial atas aktor lainnya dalam sebuah jejaring. Keempat, kekuatan untuk memprogram jaringan spesifik sesuai dengan minat dan nilai-nilai yang berbeda termasuk mengikuti aliansi strategis di antara para aktor dominan dari berbagai jaringan.

Di sisi lain, kekuatan yang terdapat dalam jejaring masyarakat di media sosial seringkali mampu melahirkan partisipasi publik yang lebih luas. Studi lain mengatakan media sosial berbasis internet sering disebut sebagai media partisipatori. Selain informatif dan interaktif, media sosial seringkali memiliki karakter partisipatoris, karena media tersebut dirancang memungkinkan setiap individu menjadi pribadi yang terlibat membentuk masyarakat di mana ia hidup di dalamnya (Bowman \& Willis, 2003). Media sosial berbasis internet dapat digunakan sebagai media untuk menyuarakan dan menyampaikan aspirasi warga negara dalam proses politik dan terlibat dalam urusan pemerintahan.

Kekuatan dan partisipasi para aktor tersebut berkembang dan melahirkan banyak aktivis di media sosial. Aktivis-aktivis tersebut dapat diklasifikasikan sebagai warganet yang sangat berperan dalam dinamika kehidupan media sosial. Berkembangnya para aktivis media sosial menyebabkan terjadinya perluasan ruang publik. Selanjutnya, media sosial dapat mentransformasikan kesadaran personal ke ruang publik baru yang lebih terbuka dan interaktif. Dengan demikian, posisi internet mampu memberikan kesempatan yang berbeda, 
sehingga jejaring tersebut berpotensi memperbarui minat atau kepentingan pada setiap keterlibatan, termasuk partisipasi warga negara (Priyono \& Hamid, 2014).

Keberadaan media sosial memberikan dukungan pada upaya pemasaran produk secara lebih cepat, hemat, dan bersifat global melalui berbagai platform (Aliami et al., 2018). Komunikasi pemasaran berbasis media sosial memanfaatkan arus informasi secara digital yang mampu menjangkau konsumen potensial secara tepat waktu, personal, dan relevan (Rony \& Panuju, 2018). Media sosial memungkinkan para penggunanya untuk saling bertukar konten dan berinteraksi satu sama lain menggunakan aplikasi berbasis web (Lazuardi, 2019). Kotler dan Keller (2016) menegaskan bahwa fungsi media sosial adalah memberikan kemampuan untuk berbagi informasi berupa teks, gambar, video, dan audio di antara individu maupun organisasi.

Media sosial telah banyak diadopsi oleh para pelaku bisnis di berbagai sektor usaha, meskipun banyak di antara mereka yang belum memanfaatkannya secara optimal (Rafiah \& Kirana, 2019). Cukup banyak platform media sosial yang digunakan masyarakat dalam berinteraksi di dunia maya. Sepuluh platform media sosial yang paling populer digunakan oleh warganet di Indonesia adalah Youtube, Whatsapp, Facebook, Instagram, Tiktok, Line, Twitter, Reddit, Pinterest, dan Tumblr (Widyananda, 2020). Penelitian ini fokus untuk menganalisis konten percakapan di platform media sosial Twitter dan Instagram sesuai dengan sasaran penggunanya di kalangan muda usia, yaitu generasi $\mathrm{Y}$ dan $\mathrm{Z}$.

\section{Aktor Warganet di Media Sosial}

Awal pemahaman istilah warganet mengacu pada pernyataan Suzuki (2007) yang menyebutkan bahwa kata netizen berasal dari kata net dan citizen. Net diartikan sebagai jejaring, sedangkan citizen dipahami sebagai warga negara atau masyarakat. Oleh karena itu, netizen atau warganet secara umum diartikan sebagai masyarakat yang terbentuk oleh jejaring digital atau internet (Soelistyowati, 2019). Warganet adalah para pengguna berbagai platform media sosial yang secara aktif berinteraksi satu sama lain secara digital di dunia maya. Pendekatan aktor sosial memandang para pengguna media sosial sebagai makhluk sosial yang berkomunikasi secara digital dan mendasarkan pada prinsip-prinsip socio-technical interaction (Prajarto, Tania, \& Purwaningtyas, 2019). Prinsip-prinsip interaksi antara aspek sosial dan teknologi tersebut meliputi jaringan tanpa batas, terjadinya perubahan secara kontinyu, simetri pada kedua aspek, serta tindakan dan struktur dalam konteks sosial dan teknologi (Sawyer \& Jarrahi, 2013).

Warganet dibedakan berdasarkan klasifikasi tingkat keaktifan mereka dalam menggunakan media sosial (Arianto, 2020a). Klasifikasi tersebut membentuk beberapa istilah berdasarkan peran mereka untuk memperkuat dan menyebarluaskan pesan atau konten digital. Peran-peran yang ada dalam masyarakat digital adalah buzzer, influencer, dan follower. Di media sosial, buzzer lebih diartikan sebagai akun yang setiap saat bertindak menyebarluaskan, mengkampanyekan, dan mendengungkan pesan atau konten digital kepada warganet lainnya dengan tujuan mempengaruhi maupun menguatkan pesan atau konten tersebut (Arianto, 2020a). Di sisi lain, influencer merupakan akun media sosial yang memiliki pengaruh sangat kuat terhadap para followersnya, sehingga akun tersebut mampu mendorong dan mempengaruhi para followers untuk bertindak sesuai yang 
dikehendaknya (Arianto, 2020a). Sesuai karakternya, follower adalah akun media sosial yang mengikuti perilaku akun influencer dan buzzer. Para follower merupakan warganet yang tunduk sesuai keinginan influencer dan buzzer yang diikutinya.

Akun media sosial yang berperan sebagai buzzer akan bertindak: (1) Membentuk dan memperkuat opini publik dalam ranah media sosial, yakni menempatkan opini tersebut pada trending topic di suatu platform media sosial; (2) Membangun isu publik yang berasal dari investigasi individu maupun influencer yang memiliki gagasan sama dengan isu tersebut; dan (3) Menyebarluaskan pesan atau konten digital di sebanyak mungkin platform media sosial, sehingga pengaruhnya akan semakin kuat atas nalar para warganet. Dalam penelitiannya, Holdford (2004) menjelaskan bahwa peran buzzer dapat memperkuat promosi obat-obatan yang dilakukan oleh apoteker melalui upaya membangun persepsi positif pada pikiran konsumen. Sesungguhnya, buzzer dalam konteks pemasaran dirancang sedemikian rupa seperti disain teatrikal agar informasi tentang produk dan jasa dapat dibicarakan secara berkelanjutan melalui jalur digital, sehingga informasi tersebut selalu dikomunikasikan satu sama lain dalam kehidupan warganet (Oosterwijk \& Loeffen, 2005).

Di sisi lain, influencer berperan pula untuk; (1) Membangun ide awal bagi pembentukan opini publik yang dapat diteruskan oleh buzzer dan follower melalui retweet, repost, maupun reshare; (2) Membangun isu atau opini melalui proses investigasi jurnalisme warga yang bertujuan untuk membantu para follower dan buzzer memahami isu atau opini yang sedang berkembang (trending); (3) Menciptakan berbagai tagar (\#) yang berpotensi menjadi trending topic dan banyak disukai oleh warganet; dan (4) Bergerak secara individual dan lebih berpegang teguh pada prinsip atau pendapat pribadi sesuai dengan isu yang sedang trending (Arianto, 2020a).

Tabel 1. Klasifikasi Aktor Warganet

\begin{tabular}{|c|c|c|c|}
\hline & Follower & Buzzer & Influencer \\
\hline Definisi & $\begin{array}{l}\text { Akun media } \\
\text { sosial yang } \\
\text { mengikuti akun } \\
\text { yang kita miliki. }\end{array}$ & $\begin{array}{l}\text { Akun media sosial yang setiap } \\
\text { saat mendengungkan atau } \\
\text { mengkampanyekan pesan } \\
\text { dengan tujuan memperkuat } \\
\text { pesan tersebut kepada } \\
\text { warganet. }\end{array}$ & $\begin{array}{l}\text { Akun media sosial yang dapat } \\
\text { mempengaruhi para follower- } \\
\text { nya untuk berbuat seperti } \\
\text { kehendaknya. }\end{array}$ \\
\hline Sifat Akun & $\begin{array}{l}\text { Anomin dan } \\
\text { nyata }\end{array}$ & $\begin{array}{l}\text { Akun Real (Positif) } \\
\text { Akun Anonim (Negatif) }\end{array}$ & Mayoritas akun nyata (real) \\
\hline $\begin{array}{l}\text { Jumlah } \\
\text { Follower }\end{array}$ & $1-500$ & $\begin{array}{l}\text { Akun Positif }>500 \\
\text { Akun Negatif }<500\end{array}$ & $>10.000$ \\
\hline
\end{tabular}

Sumber: Arianto (2020a).

Para follower selalu berusaha tampil mengikuti kehendak akun media sosial yang diikutinya. Para follower ini akan ikut memperkuat pesan yang disampaikan, baik oleh buzzer maupun influencer dengan cara meretweet, memberikan komentar, dan menyukai pesan tersebut. Dengan demikian, para aktor warganet inilah yang menentukan keberhasilan suatu pesan atau konten menarik perhatian warganet lainnya. Follower juga bisa 
ikut memviralkan konten yang berasal dari influencer maupun buzzer. Klasifikasi warganet berdasarkan tingkat keaktifan mereka ditampilkan pada Tabel 1. Tabel 1 tersebut menunjukkan rincian definisi, sifat akun, dan jumlah pengikut para aktor warganet yang meliputi buzzer, influencer, dan follower. Ketiga aktor tersebut memiliki peran kekuatan pengaruh yang berbeda-beda.

\section{Generasi Usia Muda}

Generational cohorts atau kelompok pertemanan segenerasi atau seangkatan yang diartikan sebagai sebuah kelompok yang terdiri atas individu-individu yang memiliki pengalaman dan karakteristik yang sama (Beldona, Nusair, \& Demicco, 2009). Pengertian generasi berbeda dengan cohorts. Generasi lebih ditentukan oleh waktu lahir yang sama dan berdurasi antara 20-25 tahun, sedangkan cohorts dapat memiliki durasi lebih panjang atau lebih pendek tergantung pada momen yang mereka alami bersama dan memiliki makna mendalam dan signifikan mempengaruhi kehidupan mereka (Schewe, Meredith, \& Noble, 2000). Teori perbedaan generasi membagi generasi berdasarkan pada kesamaan waktu kelahiran dan peristiwa-peristiwa bersejarah (Howe \& Strauss, 2000; Strauss \& Howe, 1991).

WJSchroer (2004) dalam Simangunsong (2018) membagi empat generasi yang umum dikenal dalam penelitian sosial, yaitu Generasi Baby Boomers, Generasi X, Generasi Y, dan Generasi Z. Generasi Baby Boomers adalah mereka yang lahir pada periode tahun 19461965, Generasi X lahir pada periode 1966-1976, Generasi Y atau generasi milenial lahir pada periode 1977-1994 (Rahulan, Troynikov, Watson, Janta, \& Senner, 2015), sedangkan Generasi Z atau net generation lahir pada periode 1995-2012 (Bhavana \& Thiruchanuru, 2018). Generasi $Y$ dan $Z$ lahir pada era perkembangan teknologi informasi, sehingga mereka memiliki keterikatan yang lebih tinggi dengan teknologi informasi, komputer, dan internet (Issa \& Isaias, 2016). Kalangan muda usia termasuk dalam Generasi Y dan Z yang disebut sebagai digital native, karena kedua generasi tersebut lahir dan tumbuh dalam perkembangan teknologi informasi di era digital (Prensky, 2001). Penelitian ini fokus pada perilaku aktor warganet muda usia, yaitu Generasi Y dan $\mathrm{Z}$ yang memainkan peran buzzer, influencer, dan follower di media sosial mereka.

\section{METODE PENELITIAN}

Penelitian ini bersifat kualitatif diskriptif. Metode penelitian kualitatif yang digunakan dalam penelitian ini adalah studi kasus. Studi kasus merupakan salah satu pendekatan penelitian kualitatif yang sengaja didisain untuk menggali dan menemukan proses atau perilaku baru sebagai obyek penelitian yang belum banyak dipahami secara luas (Dobson, 1999; Meyer, 2001). Obyek penelitian ini adalah perilaku aktor warganet, yaitu buzzer, influencer, dan follower yang menggunakan tagar (hashtag) \#HondaBeAT melalui platform media sosial Twitter dan Instagram dalam rentang waktu tanggal 13-25 Januari 2020. Pada rentang waktu tersebut, percakapan mengenai Honda Beat terlacak di aplikasi, sedangkan aplikasi Drone Emprit Academic umumnya hanya membutuhkan waktu maksimal selama 30 hari dalam membaca percakapan di media sosial. Apabila periode pengamatan melebihi waktu sebulan, maka data akan secara otomatis tidak terbaca oleh aplikasi tersebut. Hash- 
tag atau tagar merupakan sebuah fungsi di dalam media sosial yang bertugas untuk melakukan kategorisasi atau menggolongkan tema postingan yang lebih spesifik, serta mempermudah pencarian topik yang terkait (Afriani \& Mahyuzar, 2018). Dalam pemasaran digital, peran tagar sangat menentukan sekali untuk menarik perhatian warganet. Dalam sejarahnya, tanda pagar (\#) atau tagar (hashtag) merupakan kata majemuk dari label (tag) yang diberi awalan tanda pagar (hash sign atau number sign) dalam pesan layanan mikroblog. Tagar dan trending topic menjadi informasi yang memiliki otoritas tertinggi dalam demokrasi digital (Juniarto, 2016). Bahkan tagar dan trending topic seringkali menjadi salah satu alat yang mampu mendorong realitas virtual menjadi sebuah realitas aktual (Juditha, 2015).

Data yang dianalisis dalam penelitian ini berupa percakapan ketiga warganet yang diteliti pada kedua platform tersebut dan mereka berinteraksi menggunakan tagar \#HondaBeAT. Teknik pengumpulan data terhadap percakapan mereka tersebut menggunakan Social Network Analysis (SNA) dari Drone Emprit Academic (DEA) Universitas Islam Indonesia (Adji, Bashith, Nasith, \& Amin, 2019; Suharso, 2019). DEA adalah sistem yang mampu memonitor dan menganalisis media sosial dan berbagai online platform berbasis teknologi big data yang menggunakan artifial intelligence (AI) dan natural learning process (NLP), serta mampu menyajikan peta SNA tentang bagaimana fenomena sosial yang terjadi itu berasal, menyebar, siapa yang menginisiasi, dan kelompok-kelompok mana yang membicarakannya (Adji et al., 2019; Anggraeni, 2019).

Aplikasi DEA dapat menganalisis jejaring sosial secara spesifik berupa percakapan di Twitter dan Instagram secara semi-realtime dan detail. Percakapan real time dapat dibaca saat analisis ini dilakukan dan aplikasi dapat membaca percakapan sebelumnya dengan rentang waktu tidak lebih dari sepekan (Fahmi, 2019). Tahapan proses analisis dalam penelitian ini meliputi: (1) Menganalisis kumpulan percakapan warganet berdasarkan kriteria yang ditentukan, (2) Menentukan platform media sosial sasaran yaitu Twitter dan Instagram (IG); (3) Menentukan rentang waktu percakapan yang dianalisis yaitu 13-25 Januari 2020; (4) Menganalisis tagar (hashtag) dalam studi kasus ini yaitu \#HondaBeAT berdasarkan platform media sosial Twitter dan Instagram; (5) Memilah kumpulan percakapan yang terbentuk berdasarkan persentase retweet, mention, penggunaan konten image dan video, tagar (hashtag), dan akun bot; (6) Menganalisis akun-akun inisiator yang mengangkat \#HondaBeAT; dan (7) Mengidentifikasi akun aktor warganet yaitu influencer, buzzer, dan follower generasi usia muda yang menjadi sasaran dalam penelitian ini.

\section{HASIL DAN PEMBAHASAN}

\section{Gambaran Obyek Penelitian}

Penelitian ini dilakukan pada periode tanggal 13-25 Januari 2020 yang fokus pada analisis terhadap pemasaran digital produk Honda Beat. Honda Beat merupakan salah satu produk kendaraan bermotor yang memanfaatkan media sosial sebagai media pemasaran digital (Anggraini, 2018). Penggunaan media sosial untuk pemasaran digital Honda Beat tersebar hampir di semua lini media sosial. Hal tersebut dilakukan mengingat target pasar 
Honda Beat adalah para pengguna media sosial aktif, yaitu kaum muda atau generasi Y (milenial) dan generasi Z (pasca milenial).

Dengan demikian, pemasaran digital produk Honda Beat melalui media sosial cukup relevan menjadi obyek dalam penelitian ini. Pengamatan terhadap akun media sosial Honda Beat, baik berupa Twitter maupun Instagram, menunjukkan bahwa produk tersebut banyak mendapatkan followers dari warganet. Fakta itu dapat dilacak dari jumlah follower akun resmi Honda Beat pada Twitter dan Instagram (Gambar 1). Akun Twitter @welovehonda memiliki jumlah follower mencapai lebih dari 470.000 akun, sedangkan akun Instagram @welovehonda_id memiliki pengikut lebih dari 640.000 akun.

\section{Pemasaran Digital di Twitter}

Twitter merupakan salah satu media promosi digital yang dianggap cukup efektif dewasa ini (Pawestri, 2014; Dewi \& Nurjaman, 2017). Dalam mengelaborasi peran media sosial Twitter sebagai saluran pemasaran digital, penelitian ini menggunakan data percakapan Twitter yang berasal dari Drone Emprit Academic Universitas Islam Indonesia (Fahmi, 2019). Data dari Drone Emprit Academic (DEA) memperlihatkan daya tarik konten postingan verbal dan visual, persebaran percakapan secara geografis dan berdasarkan Social Network Analysis (SNA), analisis tingkat interaksi, dan analisis bot.

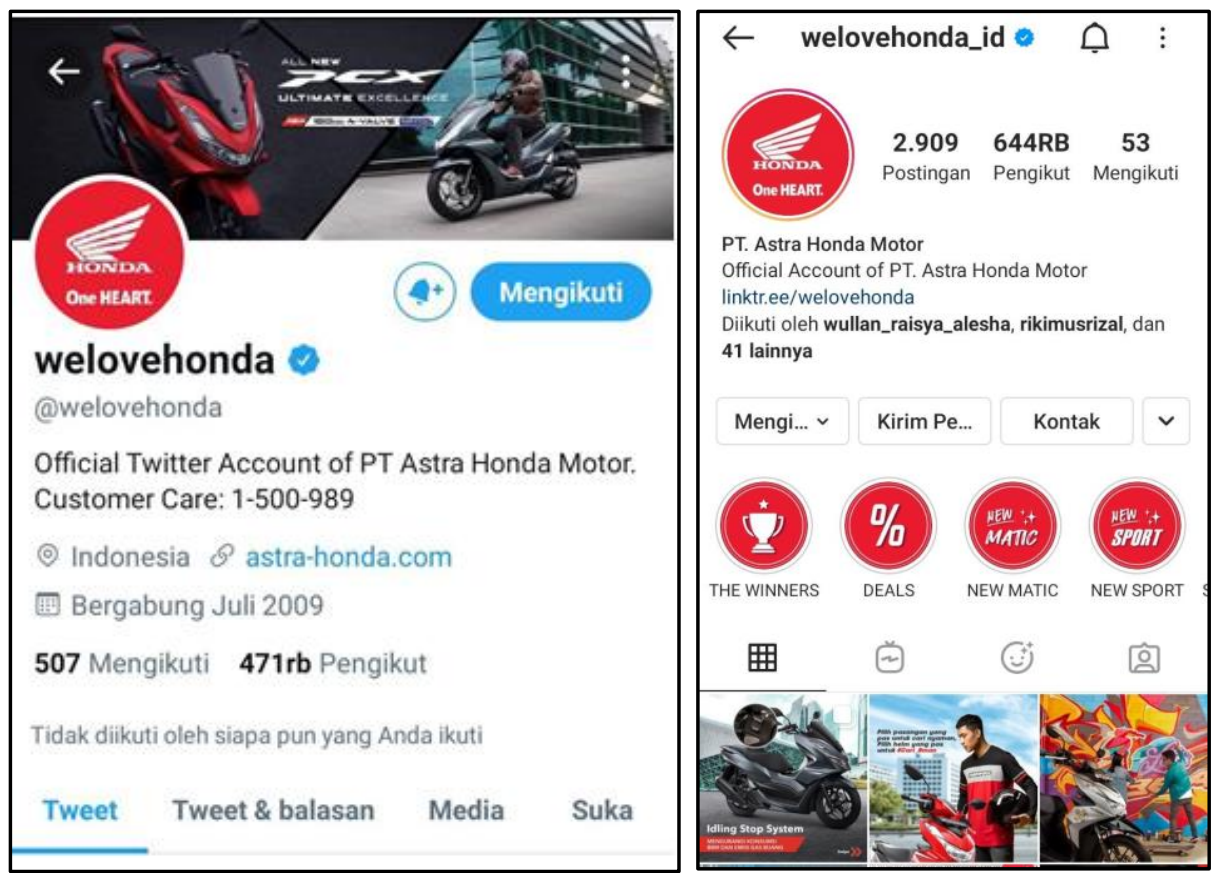

Sumber: Akun resmi PT Astra Honda Motor, Twitter (kiri) dan Instagram (kanan).

Gambar 1. Akun Resmi yang Diteliti, Twitter dan Instagram

Penggunaan tagar \#HondaBeAT untuk memperkuat pemasaran digital produk motor Honda Beat dipandang cukup berhasil menarik perhatian warganet. Hal itu dapat dilihat 
dari cukup banyaknya warganet pengguna Twitter yang terlibat memberikan komentar dalam tagar tersebut. Hal tersebut terlihat dari beberapa percakapan dalam setiap postingan di akun resmi Twitter perusahaan yaitu @welovehonda. Gambar 2 memperlihatkan beberapa contoh postingan pada akun@welovehonda menggunakan \#HondaBeAT. Gambar 2 menunjukkan contoh ekspresi beberapa warganet yang menggunakan \#HondaBeAT dalam percakapan interaktif melalui berbagai komentar. Misalnya, akun @ fikakuroo92 yang memberikan komen "kapan seri deluxe keluar," sedangkan akun@ @raiayyi berkomentar "sumpah keren, ini baru mau lunas Beat Magenta iss cbs 2017, masa mau kredit lagi, godaan apa lagi ini." Komentar warganet tersebut menunjukkan keterpengaruhan mereka dengan munculnya \#HondaBeAT yang kembali mempromosikan produk terbarunya. Pada komentar lainnya, akun @eeeekamuu menimpali percakapan dengan komen "pantes temenku yang di AHM semua post ini, ternyata ada yang baru." Selanjutnya, @pecintaDonatt memberikan komen "weewww" sebagai wujud ekspresif kekagumannya terhadap produk baru Honda Beat.

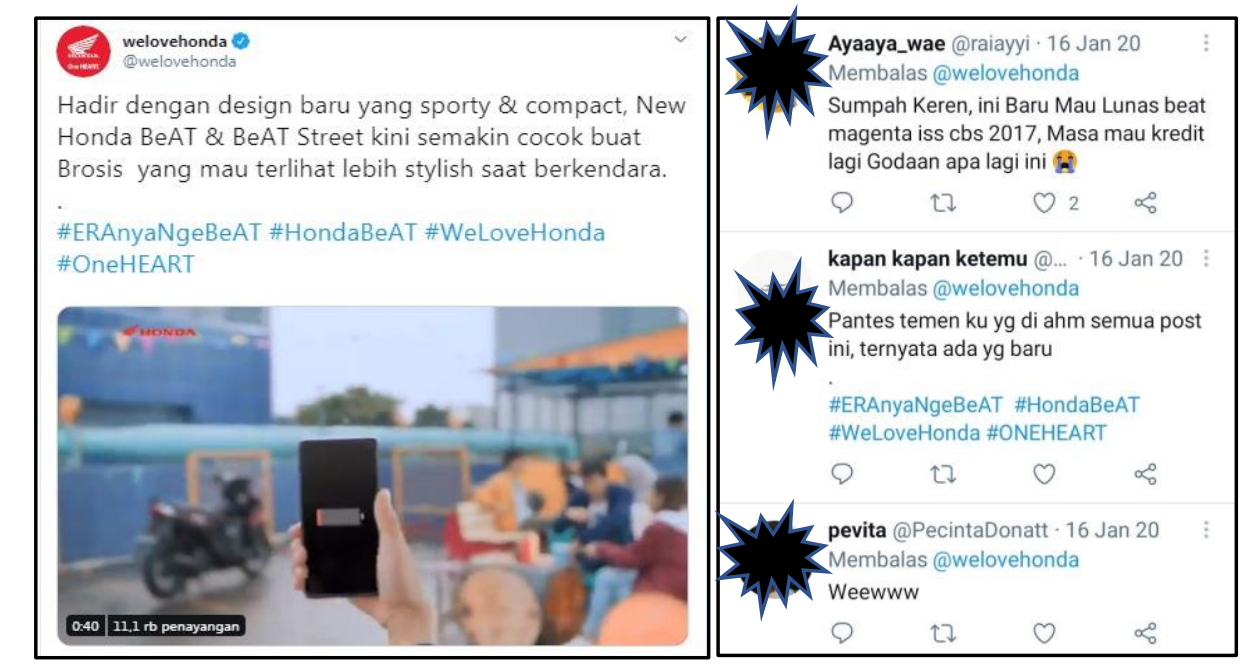

Sumber: Akun twitter resmi @welovehonda (13/01/2020).

Gambar 2. Postingan pada Akun Twitter @welovehonda

Persebaran partisipasi aktif warganet yang memberikan respon pada \#HondaBeAT berasal dari beberapa daerah di Indonesia hingga luar negeri, seperti Korea Selatan, Amerika Serikat, Philipina, dan Inggris (UK). Dari data yang dihasilkan oleh Drone Emprit Academic, daerah-daerah di Indonesia yang terpantau mempercakapkan \#HondaBeAT berasal dari wilayah Jakarta, Yogyakarta, Bekasi, Surabaya, Bandung, Semarang, Bogor, Malang, Surakarta, Tangerang, Bali, Nusa Tenggara Timur, dan beberapa daerah lainnya (Gambar 3).

Persebaran ini memperkuat anggapan bahwa media sosial memiliki cakupan yang sangat luas tidak hanya dalam jangkauan regional, tetapi hingga ke seluruh dunia. Data tersebut juga menunjukkan bahwa percakapan mengenai \#HondaBeAT di media sosial 
cukup banyak direspon oleh warganet di berbagai wilayah di Indonesia dan luar negeri, meskipun interaksinya tidak terlalu banyak. Hal tersebut dapat terlihat dari tingginya interaksi yang dihasilkan dalam kolom percakapan. Ini membuktikan bahwa produk Honda Beat cukup dikenal hampir di seluruh Indonesia hingga mancanegara.

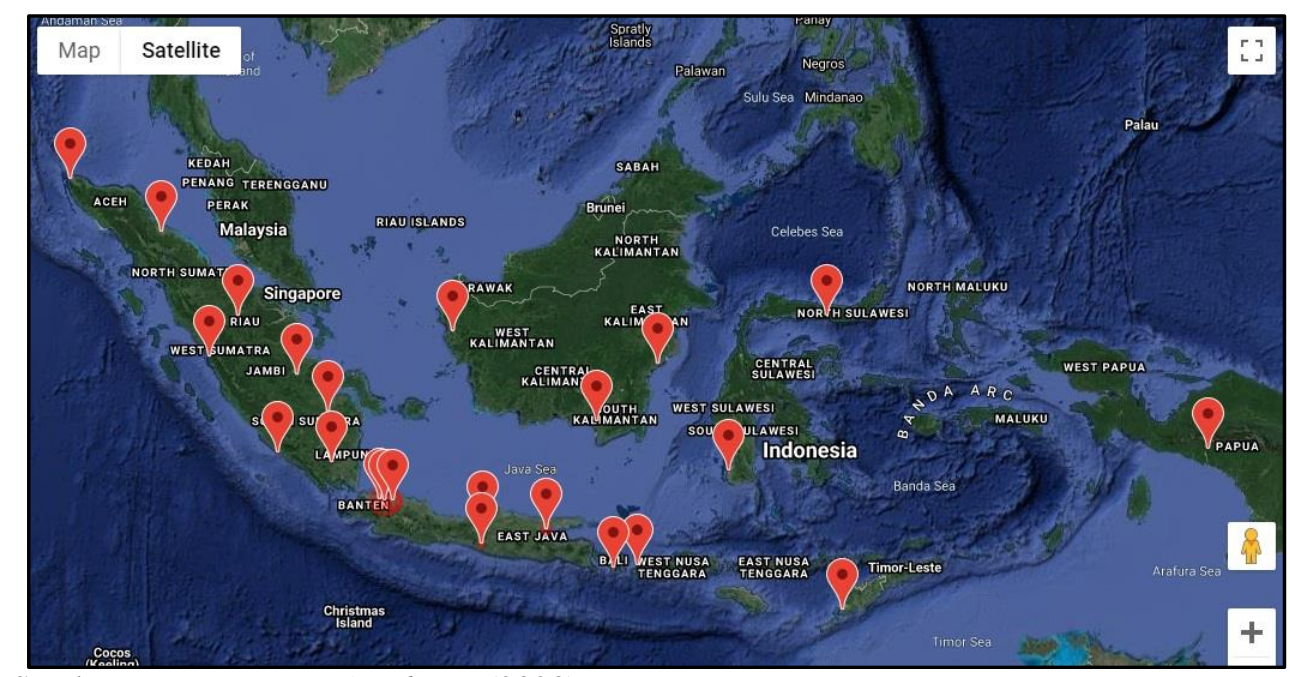

Sumber: Drone Emprit Academic (2020).

\section{Gambar 3. Persebaran Warganet yang Melakukan Percakapan dengan \#HondaBeAT}

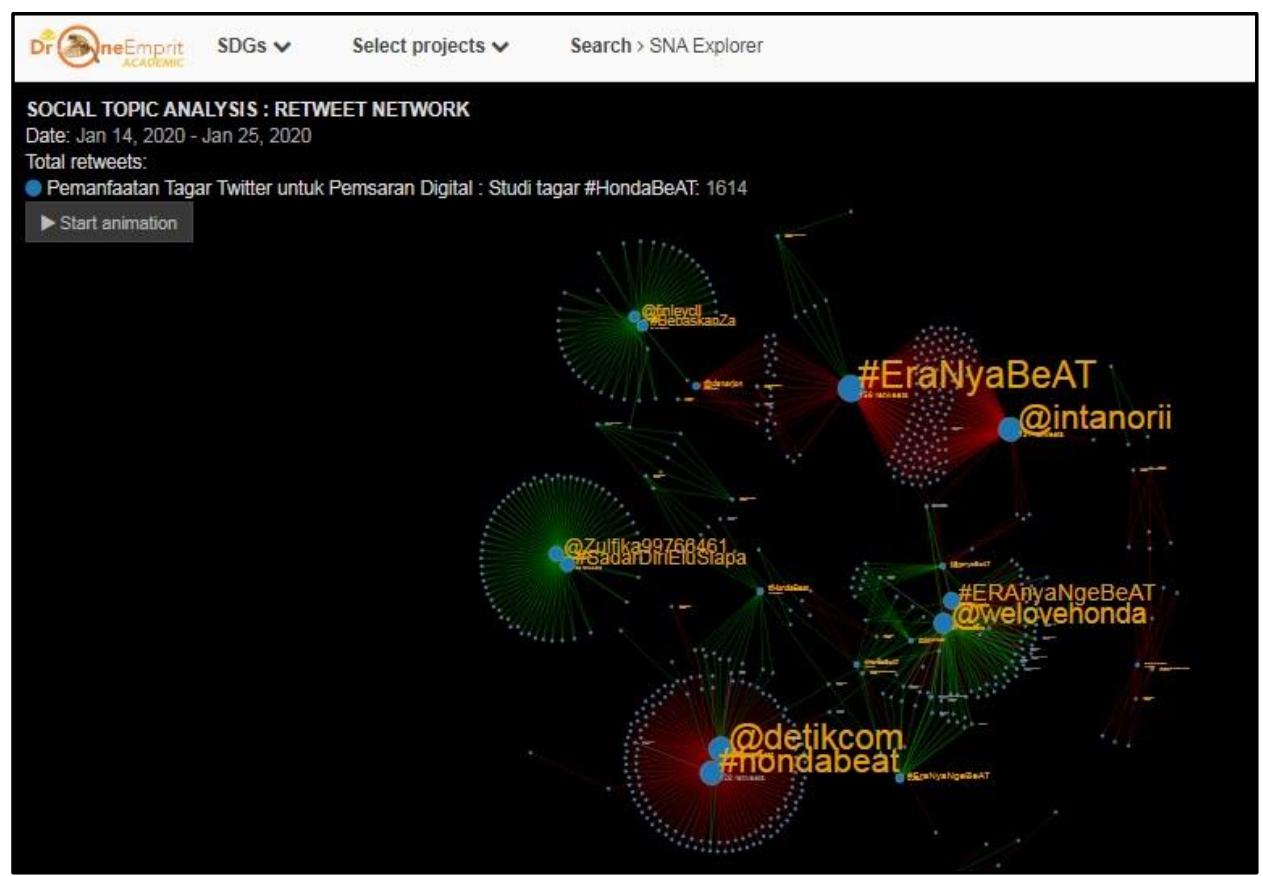

Sumber: Drone Emprit Academic (2020).

Gambar 4. Social Network Analysis (SNA) di Twitter terhadap \#HondaBeAT 
Selanjutnya, topik atau tema mengenai produk Honda Beat melalui percakapan dengan \#HondaBeAT cukup banyak dilakukan oleh warganet. Berdasarkan hasil analisis social network (SNA), \#HondaBeAT mampu meraih puncak pemberitaan atau trending topic di Twitter hingga menarik perhatian media mainstream, seperti detik.com (Gambar 4). Analisis social network adalah persebaran akun-akun yang membicarakan konten pemasaran digital oleh Honda Beat. Melalui pemberitaan oleh media mainstream, semakin banyak warganet pengguna Twitter secara otomatis akan melihat atau membaca konten berupa pesan dan percakapan dengan \#HondaBeAT, meskipun mereka tidak membuka postingan tagar tersebut. Ketika warganet melihat \#HondaBeAT, maka hashtag tersebut akan berfungsi sebagai iklan produk di media sosial. Para buzzer memiliki peran penting untuk menggaungkan \#HondaBeAT dengan memancing atau mendorong partisipasi warganet lainnya agar aktif berkomentar di media sosial resmi milik Honda tersebut. Gambar 5 menunjukkan konten percakapan \#HondaBeAT, baik berupa gambar maupun video. Penggunaan multiplatform media sosial penting untuk memperkuat pesan yang ingin disampaikan. Setiap platform membutuhkan konten dengan karakteristik yang tepat, sehingga multiplatform yang digunakan memerlukan kombinasi bentuk konten sesuai karakternya (Permana, 2019).

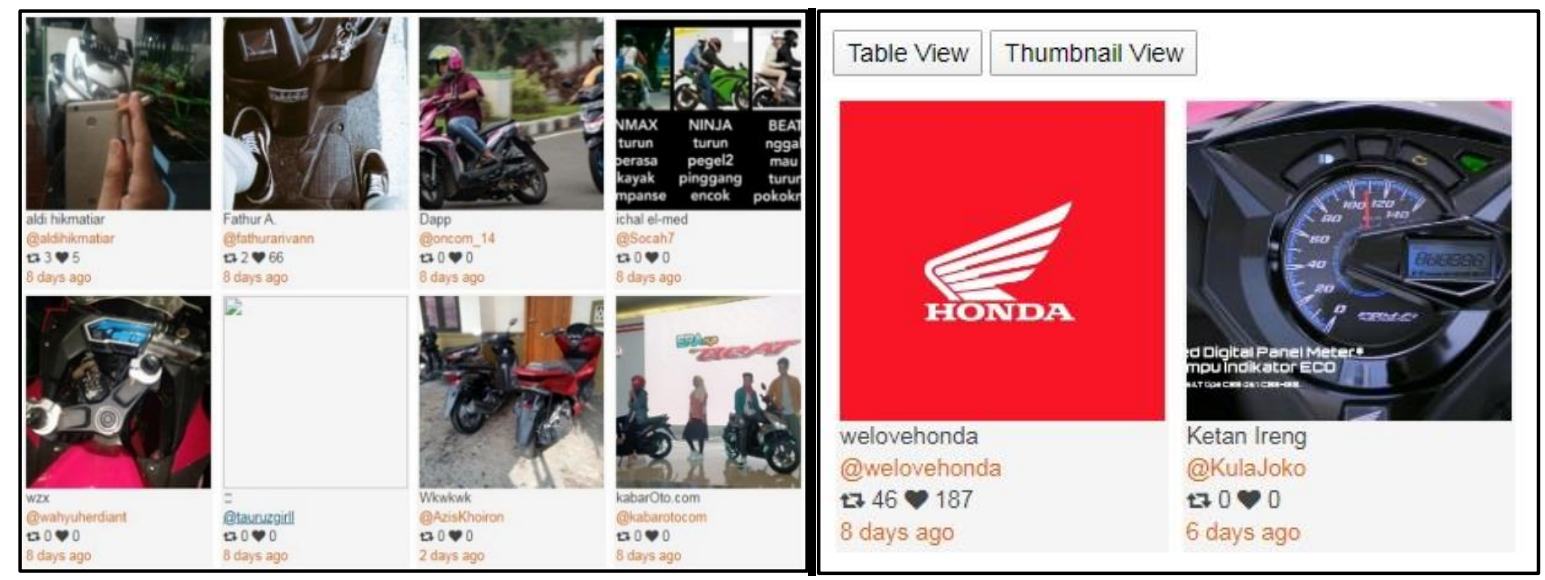

Sumber: Drone Emprit Academic (2020).

\section{Gambar 5. Konten Image (kiri) dan Video (kanan), Postingan yang Paling Disukai Warganet di Twitter}

Konten menjadi komponen utama dalam pemasaran digital. Konten dapat berupa tulisan (verbal) atau pun gambar (visual). Dengan konten yang tidak tepat, pemasaran digital perusahaan tidak akan memberikan pengaruh efektif. Untuk media sosial Twitter, konten yang paling diminati adalah video, image (gambar), dan teks. Data dari DEA menunjukkan bahwa pembuatan konten kreatif dan positif sangat menentukan keberhasilan pemasaran digital. Pemilihan karakter pada konten juga harus memperhatikan karakter warganet pengguna media sosial. Pada umumnya, beberapa konten yang mengedepankan sentuhan humor akan mendapatkan interaksi atau respon yang cukup tinggi di Twitter. Dengan demikian, pembuatan konten perlu memperhatikan pula karakter warganet peng- 
guna media sosial. Gambar 5 menunjukkan peran penting sebuah konten pada Twitter yang mampu memancing intensitas dan jumlah percakapan yang tinggi. Beberapa konten akun media sosial yang membicarakan \#HondaBeAT cukup beragam. Interaksi percakapan yang muncul ditunjukkan oleh interaction rate 2,78. Artinya, warganet memberikan komentar positif, tetapi diskusi partisipatif belum terlihat secara intensif. Semakin tinggi interaction rate, maka semakin banyak pula interaksi percakapan yang terjadi. Data pada Gambar 6 menunjukkan bahwa percakapan yang menggunakan \#HondaBeat oleh warganet mencapai total 919 kali yang terdiri atas 243 mention (26,44\%), 136 reply (14,80\%), dan 540 retweet $(58,76 \%)$.

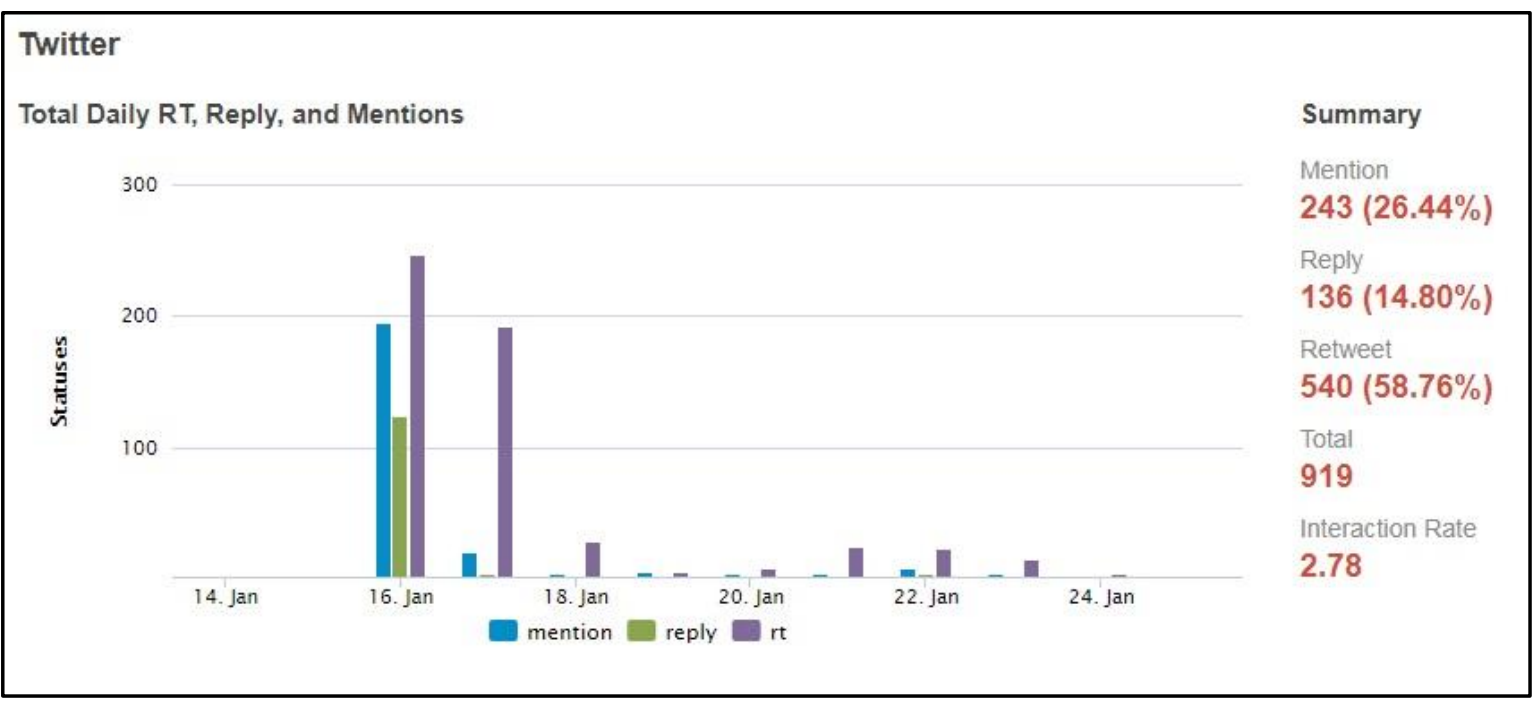

Sumber: Drone Emprit Academic (2020).

\section{Gambar 6. Analisis Tingkat Interaksi Percakapan di Twitter}

Data tersebut menunjukkan bahwa interaksi percakapan seputar Honda Beat relatif belum cukup tinggi, karena konten yang diposting termasuk konten bisnis yang memerlukan waktu dan proses untuk mendapatkan respon warganet. Dalam unggahan konten pemasaran digital, warganet yang bertugas untuk menaikkan tagar Honda Beat adalah para buzzer yang menggunakan beberapa tagar turunan agar pesannya lebih mudah dicari oleh warganet lainnya. Beberapa contoh tagar turunan yang cukup banyak menjadi perhatian warganet, sehingga masuk dalam top hashtags saat konten Honda Beat diunggah diperlihatkan pada Gambar 7. Dari beberapa percakapan tersebut, beberapa tagar (hashtag) turunannya dimunculkan, seperti \#HondaBeAT, \#HondaBeAT2020, \#EraNyaBeAT, dan \#ERAnyaNgeBeAT.

Peran dan fungsi tagar ini adalah memancing dan meningkatkan jumlah percakapan warganet yang diperkuat oleh peran aktor warganet (Afriani \& Mahyuzar, 2018), seperti buzzer dan influencer (Arianto, 2020a). Berdasarkan analisis DEA yang dilakukan dalam penelitian ini, perluasan percakapan yang cukup menonjol melalui tagar turunan di Twitter tersebut menunjukkan bahwa warganet yang ikut membicarakan tagar \#HondaBeAT 
mencapai 821 tweets, \#HondaBeAT2020 mendapatkan 183 tweets, \#EraNyaBeAT 187 tweets, dan \#ERAnyaNgeBeAT memperoleh 134 tweets (Gambar 7). Hasil ini menunjukkan bahwa partisipasi warganet cukup responsif, karena peran para aktor warganet cukup memberikan pengaruh dalam menciptakan tagar turunan yang masing-masing mendapatkan respon lebih dari 100 tweets.

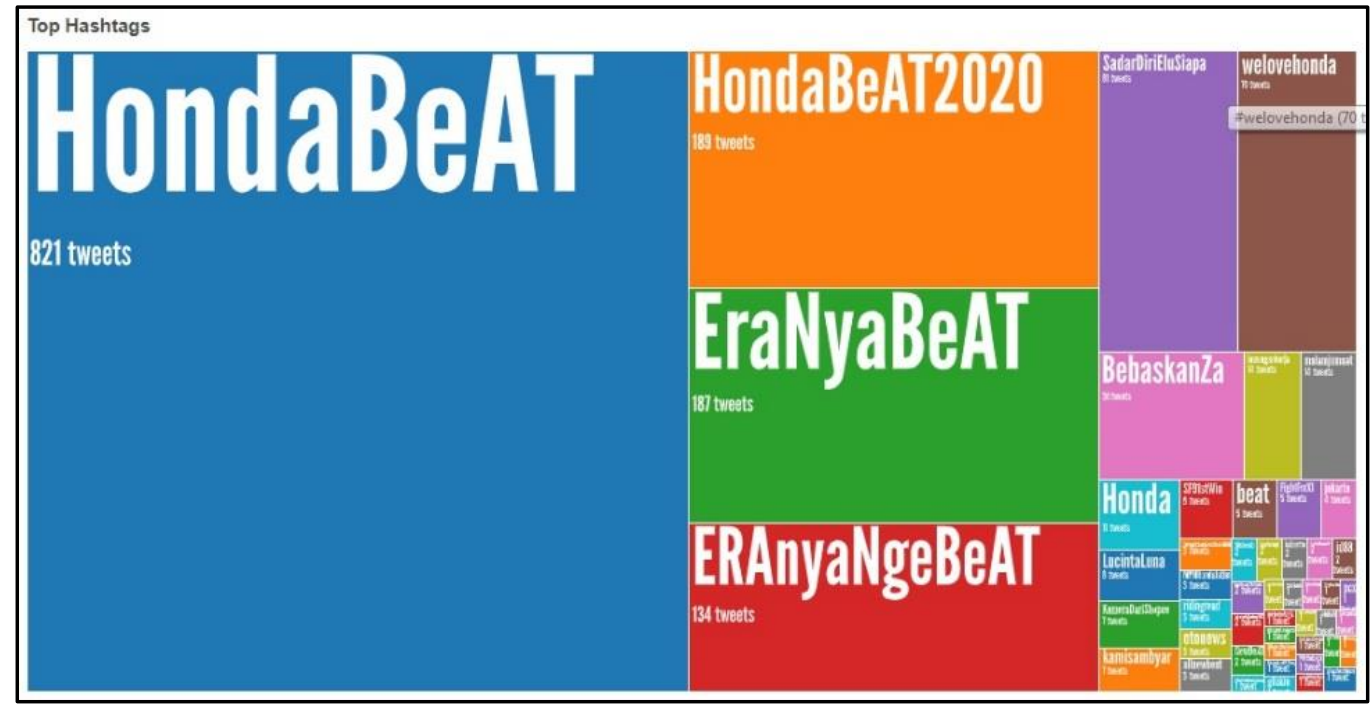

Sumber: Drone Emprit Academic (2020).

\section{Gambar 7. \#HondaBeAT sebagai Top Hashtags pada Periode Penelitian}

Analisis \#HondaBeAT di Twitter dalam penelitian ini juga dilengkapi dengan analisis bot (akun robot). Analisis akun bot di Twitter adalah akun yang dikelola oleh sebuah software yang bisa memerintah secara otomatis akun-akun lain untuk melakukan tweet, retweet, mention, like, dan sebagainya (Athallah, 2019; Dwi R., Imamah, Andre S., \& Ardiansyah, 2018). Analisis ini digunakan untuk melihat seberapa besar kemungkinan percakapan direkayasa oleh akun-akun robot. Analisis ini dapat membedakan antara percakapan yang benar-benar dilakukan oleh warganet (pemilik akun sesungguhnya) dengan percakapan yang dilakukan secara otomatis oleh akun-akun robot.

Percakapan yang mengulas tentang \#HondaBeAT di Twitter pada periode penelitian mencapai total 919 percakapan yang dapat teridentifikasi. Dari jumlah tersebut, skor bot secara keseluruhan terhadap seluruh postingan mencapai 1,73 (Gambar 8). Skor bot secara keseluruhan berkisar antara 0 hingga 5. Skor yang semakin kecil atau mendekati angka 0 (warna hijau) dapat diartikan akun bot semakin sedikit atau mayoritas yang melakukan percakapan adalah akun sesungguhnya (natural). Sebaliknya, skor yang mendekati angka 5 (warna merah) diartikan bahwa semakin banyak akun bot yang beraksi. Dengan demikian, angka skor bot sebesar 1,73 pada percakapan \#HondaBeAT menunjukkan bahwa mayoritas percakapan dilakukan oleh akun sesungguhnya, sedangkan akun robot yang turut melakukan percakapan jumlahnya relatif kecil. Temuan ini membuktikan bahwa percakapan 
dengan \#HondaBeAT yang terjadi di Twitter pada periode penelitian ini sangat alami atau bukan hasil rekayasa oleh robot yang dapat memanipulasi jumlah percakapan agar mencapai trending topic.

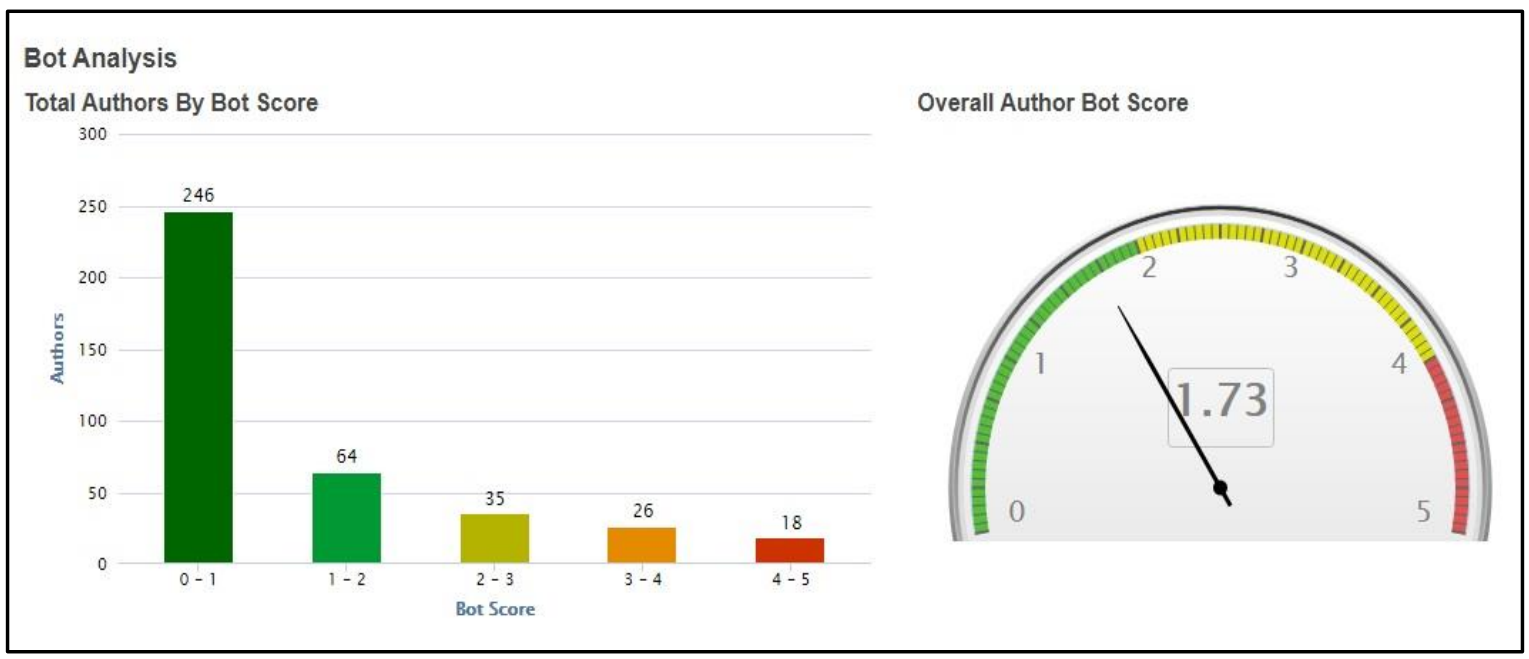

Sumber: Drone Emprit Academic (2020)

Gambar 8. Analisis Akun Bot pada Twitter

\section{Pemasaran Digital di Instagram}

Pemasaran digital melalui platform media sosial Instagram sedikit berbeda dengan Twitter. Untuk Twitter, konten yang diunggah meliputi teks, gambar, atau pun video, sedangkan Instagram lebih tepat menggunakan konten bukan teks. Hal itu disebabkan Instagram memiliki karakteristik membutuhkan konten dalam bentuk audio visual berupa gambar atau video untuk mengisi feednya (beranda). Dengan demikian, pemasaran digital menggunakan Instagram lebih tepat berbasis pada gambar atau video. Konten yang dapat menampilkan visualisasi secara kreatif dan tampil menarik akan menjadi pilihan utama warganet untuk melakukan interaksi yang berbasis Instagram.

Postingan Instagram pada akun resmi @welovehonda_id menampilkan sebuah foto produk Honda Beat hasil modifikasi bersama@r_autoworks dan @ reydecal (Gambar 9). Postingan tersebut mendapatkan cukup banyak respon, di antaranya dari akun @kevin_pranata_sembiring yang memberikan komentar memuji tampilan produk Honda Beat modifikasi dengan menggunakan kata berkonotasi positif yaitu "nice" yang secara umum diartikan sebagai ungkapan bagus atau keren terhadap sesuatu obyek, sedangkan akun@rizki_prasetyo_al_fatih memberikan tanggapan yang lebih jauh dengan menampilkan komen "naksir warna silver." Tanggapan warganet dengan kata "naksir" memiliki makna lebih jauh daripada kata nice, yaitu keinginan atau hasrat warganet yang tidak hanya sekedar tertarik (interest), tetapi ia juga memunculkan adanya niat (intention) untuk memiliki produk tersebut. Bahkan, ia telah menentukan preferensi warna yang disukainya yaitu silver. 


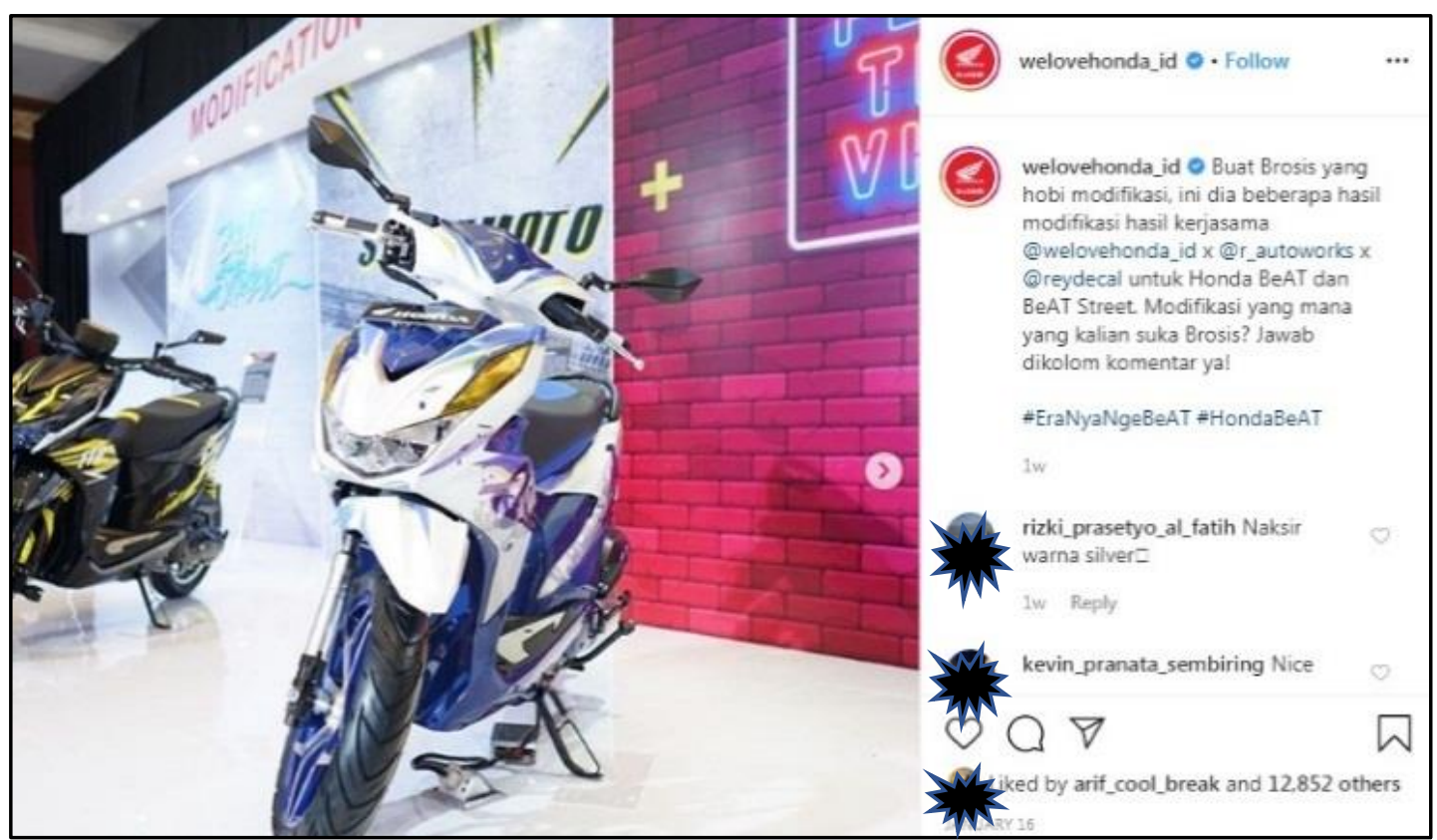

Sumber: Akun resmi Instagram @welovehonda_id (14/01/2020).

Gambar 9. Postingan pada Akun Instagram @welovehonda_id

Instagram merupakan media sosial yang fokus pada platform media sosial untuk berbagi foto maupun video. Instagram memiliki beberapa fitur menarik, seperti filter, Instagram Story, IGTV (Instagram Television), dan kemudahan berjejaring. Dalam konteks pemasaran digital, Instagram banyak digunakan oleh para pelaku bisnis untuk mempromosikan produk dan jasanya kepada warganet (Tatarina \& Husna, 2017; Ramadhan, 2017; Ardianti \& Lubis, 2020). Pada umumnya, penggunaan tagar pada Instagram dihitung selama tagar tersebut digunakan. Tagar pada IG bersifat meningkat secara kontinyu meskipun digunakan beberapa tahun ke depan atau bersifat akumulatif, sedangkan tagar pada Twitter akan muncul selama konten tersebut diposting tergantung pada waktu dan kondisi yang diinginkan. Respon warganet terhadap sebuah konten pemasaran digital menggunakan Instagram dapat dilihat dari jumlah akun yang menyukai (like) terhadap postingan konten tersebut maupun banyaknya warganet yang memberikan komentar. Dari beberapa postingan di Instagram @welovehonda_id, respon yang diperoleh dari warganet di Indonesia masing-masing mencapai lebih dari 10.000 like. Respon terhadap postingan di Instagram tersebut relatif cukup berhasil menarik perhatian warganet, sehingga upaya pemasaran @welovehonda_id dipandang relatif cukup efektif.

\section{Analisis Konten Kreatif pada Twitter dan Instagram}

Dalam pemasaran digital, kreatifitas sangat menentukan keberhasilan dalam upaya memperkuat konten, baik di Twitter maupun Instagram. Konten kreatif mampu menghipnotis warganet, karena pengaruh pilihan diksi dan tema yang menarik, luwes, mudah dimengerti, humor, dan tidak membosankan. Penggunaan konten kreatif dapat membangun komunikasi yang inspiratif langsung kepada warganet sebagai sasaran dan sekaligus 
menjadi metode kampanye yang berorientasi pada pemberdayaan jangka panjang, seperti pembangunan citra positif melalui branding terhadap produk (Arianto, 2020b). Dalam penelitian ini, beberapa postingan di Twitter yang hanya menggunakan konten kreatif berupa teks terbukti cukup mampu menarik perhatian warganet. Misalnya, warganet dengan akun @intanorii dan @Santi_nya (Gambar 10). Kedua warganet tersebut tidak menggunakan materi gambar (image) atau video dalam percakapan \#HondaBeAT. Hal itu menunjukkan bahwa pemasaran digital melalui Twitter relatif lebih sederhana daripada Instagram. Dalam upaya memperkuat strategi pemasaran digital dengan \#HondaBeAT, berbagai konten kreatif, seperti video, gambar (image), dan teks pun digunakan. Untuk teks (verbal), akun buzzer di Twitter lebih diutamakan agar lebih berperan melalui kreasi mereka masingmasing.

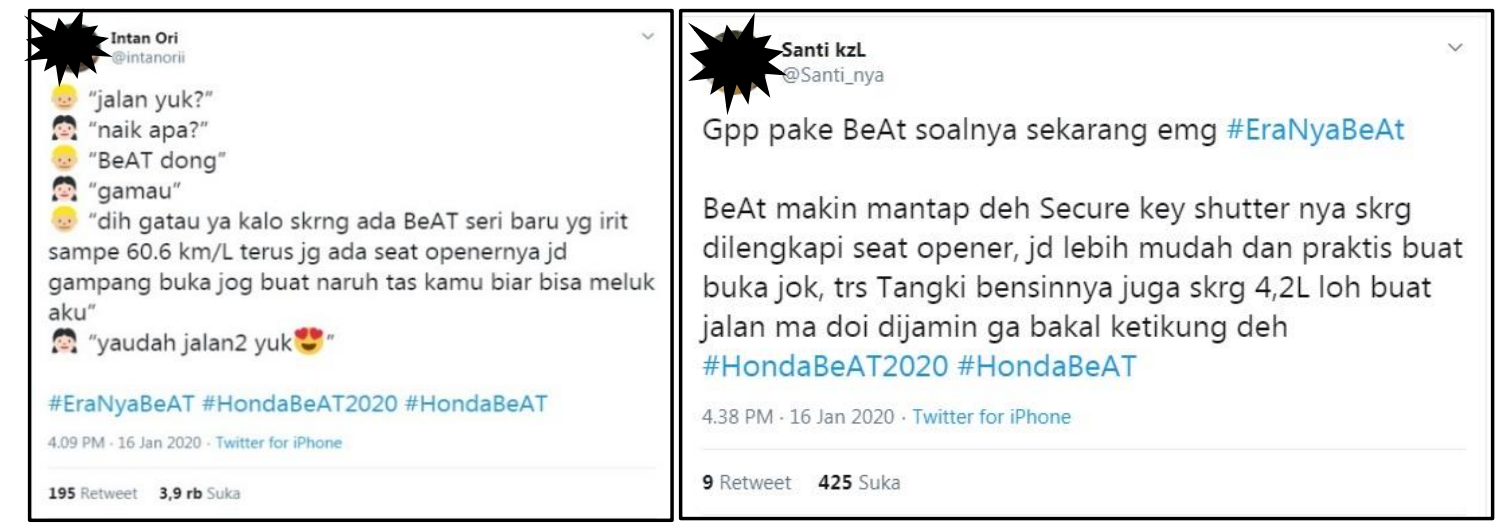

Sumber: Drone Emprit Academic (2020).

\section{Gambar 10. Contoh Postingan Verbal Warganet di Twitter}

Gambar 10 menunjukkan bahwa konten dalam bentuk teks (verbal) yang diunggah oleh para buzzer bertujuan untuk menarik perhatian warganet lainnya. Teks disusun dengan bahasa sendiri atau memiliki ciri khas tersendiri lebih disukai warganet lain terutama follower mereka. Dari kedua postingan konten pada Gambar 10, para buzzer berupaya menggunakan frase yang lebih sesuai dengan ciri khas mereka masing-masing, sehingga para followersnya dapat menyukainya. Apabila para followers tertarik, maka pesan-pesan tersebut dapat tersampaikan sesuai targetnya. Dengan demikian, peran konten dan pemilihan konten di dalam pemasaran digital harus disesuaikan dengan karakteristik media sosial yang digunakan. Ketidaktepatan pemilihan jenis konten untuk setiap akun media sosial dapat berakibat minimnya partisipasi para followers untuk berinteraksi memberikan komentar balasan.

Dalam penelitian ini, akun utama yang diposisikan sebagai influencer untuk melaksanakan pemasaran digital ini adalah akun@welovehonda. Sebagai akun influencer, akun tersebut memberikan pengaruh kepada follower dan buzzer agar mereka turut berperan meramaikan percakapan dan mampu memperkuat \#HondaBeAT untuk meraih kategori trending topic. Keberhasilan buzzer turut menarik perhatian warganet lainnya agar 
bersama-sama mengangkat tagar yang sama bersama-sama. Di sisi lain, konten yang digunakan dalam Instagram sebatas hanya pada tampilan video dan gambar (image) saja.

\section{Peran Aktor Warganet}

Penelitian ini mengungkap peran penting tiga aktor warganet, yaitu followers (pengikut), influencer (yang memberikan pengaruh), dan buzzer (pendengung). Strategi pemasaran digital secanggih apa pun menjadi percuma, apabila tidak memiliki akun followers yang memadai untuk memviralkan pesan (Storemantap, 2016). Secara prinsip, followers telah memiliki pengetahuan mendasar tentang akun yang diikutinya. Meskipun mereka belum melakukan sesuai pesan yang disampaikan, tetapi followers dapat diposisikan sebagai agen secara tidak resmi yang mau dan mampu meneruskan pesan konten pemasaran produk. Akun yang memiliki semakin banyak followers akan menjadi akun favorit sebagai influencer, karena berpotensi memiliki kemampuan membentuk opini yang diinginkannya kepada para followers mereka guna meningkatkan keefektifan pemasaran digital (Hanindharputri \& Putra, 2019). Respon yang akan diperoleh akun influencer pun berpotensi semakin banyak, sehingga pesan yang dibawanya berkesempatan meraih trending topic. Buzzer adalah akun yang berperan penting melakukan postingan tentang suatu konten secara berulang, sehingga pesan tersebut dapat diterima audiens sasaran (Oliver, 2021). Pesan yang disampaikan secara berulang merupakan upaya untuk memperkuat pesan dalam pemasaran digital (Arianto, 2020a).

Dalam penelitian ini, akun utama yang melemparkan pesan \#HondaBeAT adalah akun @welovehonda. Data Drone Emprit Academic (2020) menunjukkan bahwa \#HondaBeAT diperkuat oleh beberapa akun influencer yang menduduki peringkat atas top users. Isu utama \#HondaBeAT didisain sedemikian rupa dalam bentuk konten digital untuk memancing respon warganet. Semakin menarik disain konten, maka pengaruhnya juga semakin efektif untuk mendapatkan efek domino atau multiplier effect berupa respon positif warganet. Berdasarkan data DEA (2020), akun-akun influencer yang teridentifikasi memposting \#HondaBeAT dan memiliki kemampuan mempengaruhi warganet adalah @detikcom, @welovehonda, @intanorii, @fermendkis, dan @infoPKU. Kelimanya terdeteksi menjadi top users berdasarkan impact yang diraih karena postingannya (Gambar 11). Di pemasaran digital, postingan oleh akun top users akan diterima dan berpotensi tinggi untuk direspon balik oleh akun-akun followers maupun buzzer.

Data pada Gambar 11 menunjukkan lima akun top users yang teridentifikasi berdasarkan impact terbesar. Sesuai tujuan pemasaran, akun yang memberikan impact semakin besar merupakan akun influencer yang dapat diandalkan oleh Honda untuk menyampaikan dan menguatkan pesan promosi merek Honda Beat melalui \#HondaBeAT. Besarnya impact juga mengindikasikan jumlah followers yang mengikuti kelima akun utama tersebut cukup besar. Selain kekuatan impact, Gambar 11 juga menunjukkan data potential reach masing-masing akun. Reach merupakan suatu tolok ukur yang menunjukkan jumlah akun yang membaca sebuah konten digital (Rahmalia, 2021).

Berdasarkan data potential reach dan impact tersebut, \#HondaBeAT berpotensi untuk dibaca oleh lebih dari 17 juta pengguna akun Twitter dan mampu memberikan impact kepada hampir 85 juta akun secara keseluruhan. Selain itu, data tersebut juga menunjukkan 
bahwa engagement rate yang dipahami sebagai tingkat keterlibatan warganet terhadap postingan yang ditampilkan oleh influencer maupun buzzer (Oliver, 2021). Sebagian besar followers cenderung menghindari postingan akun yang mereka identifikasikan sebagai buzzer, sedangkan mereka lebih suka terlibat aktif secara natural dengan akun influencer. Dari data tersebut, tingkat keterlibatan warganet yang berada pada titik tertinggi yaitu 11 terjadi pada akun @welovehonda. Ini menunjukkan bahwa sebagian besar warganet memiliki kepercayaan lebih besar terhadap akun resmi Honda Beat daripada empat akun utama lainnya terkait \#HondaBeAT.

\begin{tabular}{|c|c|c|c|c|c|}
\hline \multicolumn{6}{|c|}{ Top Users by Impact } \\
\hline Avatar & Name & Account Name & Engagement & Potential Reach & Impact \\
\hline & detikcom & detikcom & 5 & 15.619 .121 & 78.095 .605 \\
\hline & welovehonda & welovehonda & 11 & 475.779 & 5.233 .569 \\
\hline & Intan Ori & intanorii & 2 & 442.175 & 884.350 \\
\hline & menda 2 & fermendkis & 2 & 232.198 & 464.396 \\
\hline & Informasi Pekanbaru & infoPKU & 1 & 232.374 & 232.374 \\
\hline & Jumlah & & 21 & 17.001 .647 & 84.910 .294 \\
\hline
\end{tabular}

Sumber: Drone Emprit Academic (2020).

\section{Gambar 11. Akun Utama yang Melontarkan \#HondaBeAT di Twitter}

Selanjutnya, akun buzzer yang muncul pada \#HondaBeAT dikategorikan sebagai buzzer bisnis, karena akun tersebut berupaya memperkuat konten bisnis dalam rangka pemasaran digital produk Honda Beat. Sebaimana tugas utamanya, akun buzzer bisnis berupaya memperkuat konten pemasaran digital Honda Beat melalui aktifitas postingan \#HondaBeAT secara berulang. Akun buzzer bisnis ini bertugas mendorong warganet termasuk followers untuk berkomentar (mention), menjawab (reply), melakukan tweet ulang (retweet), atau sekedar memberikan respon suka (like) terhadap postingannya. Semakin banyak interaksi warganet yang muncul dalam postingan \#HondaBeAT, maka semakin tinggi keberhasilan tugas buzzer dalam pemasaran digital ini.

Selain itu, aktor warganet berperan penting sebagai komunikator agar konten \#HondaBeAT dapat semakin tersebar luas dan banyak dibicarakan warganet. Penyebaran informasi secara masif inilah yang dikenal dalam pemasaran viral (viral marketing) yang menekankan pada pentingnya mendapatkan pengunjung website sebanyak mungkin 
(Andini, Suharyono, \& Sunarti, 2014). Dalam penelitian ini, yang dimaksud dengan pengunjung website adalah aktor-aktor warganet yang mempercakapkan \#HondaBeAT. Semakin banyak warganet yang memperbincangkan konten ini di media sosial, maka semakin berhasil kiprah aktor warganet tersebut. Dengan demikian, semakin efektif pula pemasaran digital \#HondaBeAT. Data percakapan Twitter dalam periode pengamatan, yaitu tanggal 13-25 Januari 2020 mendapatkan 1.614 percakapan yang menggunakan tagar \#HondaBeAT, sedangkan pada Instagram untuk periode yang sama diperoleh 187.655 postingan \#HondaBeAT. Percakapan tagar pada Twitter muncul berdasarkan durasi waktu tertentu. Dalam penelitian ini, \#HondaBeAT hanya muncul di Twitter pada tanggal 15 Januari 2020. Meskipun hanya 1.614 kali postingan, tetapi tagar tersebut mampu meraih trending topic di Indonesia. Di sisi lain, \#HondaBeAT pada Instagram terakumulasi secara kontinyu dari sejak pertama kali diposting hingga percakapan tersebut hilang dengan sendirinya pada suatu saat nanti, ketika tagar tersebut tidak lagi digunakan atau diperbincangkan oleh warganet. Tidak seperti di Twitter, platform Instagram tidak menyediakan fitur trending topic.

\section{KESIMPULAN DAN SARAN}

Penggunaan berbagai platform media sosial sebagai saluran pemasaran digital semakin banyak digunakan perusahaan, karena strategi tersebut terbukti lebih efektif dan efisien untuk memperkenalkan produk daripada strategi promosi secara konvensional. Analisis data dalam penelitian ini menggunakan analisis Drone Emprit Academic (DEA). Temuan dalam penelitian ini menunjukkan interaksi percakapan konten \#HondaBeAT yang cukup tinggi, baik melalui Twitter maupun Instagram. Tingkat interaksi tersebut menunjukkan bahwa \#HondaBeAT mendapatkan respon cukup positif dari warganet. Keberhasilan pemasaran digital \#HondaBeAT tidak dapat dilepaskan dari kiprah aktor warganet seperti influencer, follower, dan buzzer.

Media sosial memiliki peran penting untuk memperkuat ekosistem pemasaran digital. Dampak pengganda percakapan menjadi lebih besar ketika media mainstream dan akun top users turut andil meneruskan penyampaian pesan kepada warganet. Akun top users merupakan akun warganet yang memiliki jumlah followers yang banyak dan berkemampuan untuk mempengaruhi warganet lain dengan jumlah yang cenderung semakin besar. Sesuai tugasnya, akun buzzer diperlukan untuk mendengungkan \#HondaBeAT secara berulang dalam jangka waktu tertentu. Dalam pemasaran, teknik pengulangan diperlukan untuk memicu kesadaran dan memperkuat retensi konsumen terhadap pesan yang disampaikan. Namun, semakin tinginya tingkat literasi konsumen, kepercayaan terhadap buzzer pun terlihat mulai selektif dilakukan konsumen. Konsumen mulai mampu mengidentifikasi buzzer bisnis dan buzzer yang bertindak secara sukarela.

Temuan dalam penelitian ini mengkonfirmasi maupun memperkuat berbagai analisis pada penelitian sebelumnya yang mengungkapkan bahwa media sosial dapat dimanfaatkan untuk meningkatkan kepercayaan konsumen maupun publik pada umumnya melalui kreatifitas penggunaan platform sesuai karakter audiens sasarannya. Dari temuan tersebut, perusahaan dapat memanfaatkan platform media sosial secara tepat sasaran mengikuti pola 
kesukaan warganet, misalnya penyebaran informasi melalui teknik hashtags. Penelitian ini memiliki keterbatasan pada cakupan platform yang diteliti, periode waktu pengamatan, dan jumlah aktor warganet yang dianalisis. Penelitian mendatang disarankan untuk mengantisipasi keterbatasan tersebut.

\section{DAFTAR REFERENSI}

Adji, W. S., Bashith, A., Nasith, A., \& Amin, S. (2019). Identification of Social Symptoms Using the Drone Emprit Academic as a Support for Statistical Literacy. Abjadia:

International Journal of Education, 4(2), 97-106. https://doi.org/10.18860/abj.v4i2.8412.

Afriani, D., \& Mahyuzar, M. (2018). Penggunaan Hashtag sebagai Varian Promosi Produk pada Media Sosial Instagram. Jurnal Ilmiah Mahasiswa FISIP Unsyiah, 3(2), 113124.

Akmal, I., \& Irwansyah, I. (2020). Peran Aktivis Media Sosial (Buzzer) Sukarela: Studi Kasus Member Independen Herbalife Nutrition. Calathu: Jurnal Ilmu Komunikasi, 2(2), 115-131.

Aliami, S., Hakimah, E. N., Fauji, D. A. S. (2018). Dampak Pengembangan Pemasaran Digital pada Startup's (Studi Kasus pada Wirausaha Baru). EkoNiKa: Jurnal Ekonomi Universitas Kadiri, 3(1), 73-87.

Amalina, A. (2016). Pengaruh Social Media Marketing terhadap Brand Loyalty dengan Brand Trust sebagai Variabel Intervening (Studi pada Follower Twitter Mizone Mizoneid). Jurnal Ilmu Manajemen (JIM), 4(3), 1-12

Andini, N. P., Suharyono, S., \& Sunarti, S. (2014). Pengaruh Viral Marketing terhadap Kepercayaan Pelanggan dan Keputusan Pembelian: Studi pada Pembelian Online melalui Media Sosial Instagram. Jurnal Administrasi Bisnis, 11(1), 1-6.

Andriyanto, R. D., \& Haryanto, J. O. (2010). Analisis Pengaruh Internet Marketing terhadap Pembentukan Word of Mouth and Brand Awareness untuk memunculkan Intention to Buy. Journal of Technology Management, 9(1), 115-433.

Anggraeni, V. A. (2019). Drone Emprit Buatan Anak Bangsa. GoodNews from Indonesia, 22 Mei 2019. Diakses 23 Juli 2020 di

https://www.goodnewsfromindonesia.id/2019/05/22/drone-emprit-buatan-anakbangsa.

Anggraini, N. (2018). Strategi Pemasaran Sepeda Motor Merek Honda Tipe Matic (Studi Kasus PT Hoho Pekanbaru). eCo-Buss, 1(2), 33-39.

Ardianti, F., \& Lubis, D. P. (2020). Efektivitas Instagram sebagai Media Promosi Desa Wisata Malasari, Kecamatan Nanggung, Kabupaten Bogor. Jurnal Sains Komunikasi dan Pengembangan Masyarakat [JSKPM], 4(6), 796-809.

Arianto, B. (2020a). Peran Buzzer Media Sosial dalam Memperkuat Ekosistem Pemasaran Digital. Jurnal Optimum, 10(1), 52-65.

Arianto, B. (2020b). Pemanfaatan Aplikasi Drone Emprit Academic dalam Menganalisis Opini Publik di Media Sosial. Journal of Social Politics and Governance, 2(2), 177191. 
Asriani, A. (2011). Pemanfaatan Internet Marketing dalam Pemasaran Produk Unggulan Pertanian Provinsi Gorontalo. Jurnal Komunikasi Kareba, 3(1), 249-257.

Athallah, R. A. (2019). Memanipulasi Publik Lewat Akun Bot Twitter. Mediapedia, 7 Juli. https://www.remotivi.or.id/mediapedia/551/memanipulasi-publik-lewat-akun-bottwitter.

Ayuningtyas, A., \& Lailiyah, N. (2019). Sikap Followers, Terkait Nurhadi-Aldo dalam Media Sosial Instagram dan Twitter. Interaksi Online, 7(4), 385-396.

Beldona, S., Nusair, K., \& Demicco, F. (2009). Online Travel Purchase Behavior of Generational Cohorts: A Longitudinal Study. Journal of Hospitality Marketing \& Management, 18(4), 406-420. https://doi.org/10.1080/19368620902799627.

Bhavana, A., \& Thiruchanuru, S. (2018). Green Marketing: Gap Analysis in the Decision Making Process of a Green Consumer. Journal of Business Management \& Social Sciences Research, 7(3), 50-57.

Bowman, B. S., \& Willis, C. (2003). We Media: How Audiences are Shaping the Future of News and Information. California: The Media Center at the American Press Institute.

Castells, M. (2007). Communication, Power and Counter-power in the Network Society. International Journal of Communication, 1, 238-266.

CNBC Indonesia (2018). Alasan Milenial Lebih Suka Gunakan Snapchat dan Instagram. https://www.cnbcindonesia.com/lifestyle/20180311103732-33-6865/alasan-mileniallebih-suka-gunakan-snapchat-dan-instagram. Diakses 9 Juli 2020.

Dewi, R. U., \& Nurjaman, Z. Z. (2017). Penggunaan Jejaring Sosial Twitter sebagai Media Promosi pada Restoran Ranjang 69. Commed: Jurnal Komunikasi dan Media, 1(2), 51-67.

Dobson, P. J. (1999). Approaches to Theory Use In Interpretive Case Studies - a Critical Realist Perspective. 10th Australasian Conference on Information Systems Churchlands: Edith Cowan University, 259-270.

Dwi R., A., Imamah, F., Andre S., Y. M., \& Ardiansyah, A. (2018). Aplikasi Chatbot (Milki Bot) yang Terintegrasi dengan Web CMS untuk Customer Service pada UKM Minsu. Jurnal Cendikia, XVI, 100-106.

Fahmi, I. (2019). Drone Emprit Academic: Software for Social Media Monitoring and Analytics. Available at http://uii.ac.id.

Gityandraputra, D. (2020). Hal yang Penting Diketahui untuk Konten Video di Media Sosial. Marketingcraft, 26 Mei. Diakses tanggal 22 Juli 2020 di https://marketingcraft.getcraft.com/id-articles/hal-penting-untuk-video-di-mediasosial.

Handajani, L., Akram, A., Furkan, L. M., \& Rifa'i, A. (2019). Penggunaan Pemasaran Digital pada Usaha Home Industry Kopi Lombok di Desa Sigerongan Kabupaten Lombok Barat. Jurnal Abdi Insani LPPM Unram, 6(3), 409-421. http://doi.org/10.29303/abdiinsani.v6i3.267.

Hanindharputri, M. A., \& Putra, I. K. A. M. (2019). Peran Influencer dalam Strategi Meningkatkan Promosi dari Suatu Brand. Sandyakala: Prosiding Seminar Nasional Seni, Kriya, dan Desain 2019, 1, Institut Seni Indonesia Denpasar, 335-343. 
Holdford, D. A. (2004). Using Buzz Marketing to Promote Ideas, Services, and Products. Journal of the American Pharmacists Association, 44(3), 387-396.

Howe, N., \& Strauss, W. (2000). Millennials Rising: The Next Great Generation. New York: Random House, Inc.

Iman, M. (2020). Pengguna Instagram di Indonesia Didominasi Wanita dan Generasi Milenial. GoodNews from Indonesia, 14 Juni 2020. Diakses 9 Juli 2020 di https://www.goodnewsfromindonesia.id/2020/06/14/pengguna-instagram-diindonesia-didominasi-wanita-dan-generasi-milenial.

iProspect (2007). iProspect Social Networking User Behavior Study. Retrieved from http://www.iprospect.com/premiumPDFs/researchstudy_2007_socialnetworkingbeha vior.pdf.

Issa, T., \& Isaias, P. (2016). Internet Factors Influencing Generations $\mathrm{Y}$ and $\mathrm{Z}$ in Australia and Portugal: A Practical Study. Information Processing and Management, 52(4), 592-617. https://doi.org/10.1016/j.ipm.2015.12.006.

Itworks.id (2019). Demografi Pengguna Twitter di Indonesia Paling Banyak Pria daripada Perempuan. (Online). https://www.itworks.id/19408/demografi-pengguna-twitter-diindonesia-paling-banyak-pria-daripada-perempuan.html. Diakses 9 Juli 2020.

Juditha, C. (2015). Fenomena Trending Topic di Twitter: Analisis Wacana Twit \#savehajilulung. Jurnal Penelitian Komunikasi dan Pembangunan, 16(2), 138-154.

Juniarto, D. (2016). Menyoal Demokrasi Digital di Indonesia. Jurnal Dialog Kebijakan Publik, 22(Desember), 28-35.

Kaplan, A. \& Haenlein, M. (2010). Users of the World, Unite! The Challenges and Opportunities of Social Media. Business Horizons, 53(1), 59-68.

Karinov.co.id. (2018). Mengenal Digital Marketing, Pengertian, dan Caranya. 19 Juli. Diakses tanggal 22 Juli 2020 di https://karinov.co.id/mengenal-apa-itu-digitalmarketing.

Kontan.co.id (2013). Perusahaan Tak Sembarang Menggaet Buzzer. Diakses tanggal 9 Juli 2020 di https://industri.kontan.co.id/news/perusahaan-tak-sembarang-menggaetbuzzer.

Kotler, P., \& Armstrong, G. (2012). Principles of Marketing. 14th Edition. New Jersey: Pearson Education, Inc.

Kotler, P., \& Keller, K. L. (2016). A Framework for Marketing Management. Sixth Edition. Harlow: Pearson Education, Ltd.

Kumparan.com (2018). Riset Beda Media Sosial, Beda Karakter Penggunanya. Diakses tanggal 10 Januari 2020 di https://kumparan.com/millennial/riset-beda-media-sosialbeda-karakter-penggunanya-1542093888201539387.

Lazuardi, V. G. (2019). Pengaruh Pemasaran Media Sosial, Identifikasi Sosial, dan Nilai Persepsi terhadap Kepuasan pada Produk Indomie (Studi pada Konsumen Digital Produk Indomie). Jurnal Ilmiah Mahasiswa FEB Universitas Brawijaya, 8(1).

Maulana, I., \& Salsabila, O. (2020). Pengaruh Social Media Influencer terhadap Perilaku Konsumtif di Era Ekonomi Digital. Majalah Ilmiah Bijak, 17(1), 28-34. 
Meyer, C. B. (2001). A Case in Case Study Methodology. Field Methods, 13(4), 329-352.

Oliver, A. (2021). Yuk, Pahami 3 Perbedaan Buzzer dan Influencer. Glints Blog, Marketing Communication, 29 Maret. https://glints.com/id/lowongan/perbedaan-buzzer-daninfluencer/\#.YGXCvvkzbIW.

Oosterwijk, L., \& Loeffen, A . (2005). How to Use Buzz Marketing Effectively: A New Marketing Phenomenon Explained and made practical. Unpublished master's thesis, Sweden, Mälardalen University.

Pawestri, I. A. (2014). Twitter sebagai Media Promosi Wisata Kota Semarang. An-Nida: Jurnal Komunikasi Islam, 6(2), 101-110.

Pelsmacker, P. D., Tilburg, S. V., \& Holthof, C. (2018). Digital Marketing Strategies, Online Reviews and Hotel Performance. International Journal of Hospitality Management, 72, 47-55. https://doi.org/10.1016/j.ijhm.2018.01.003.

Permana, A. (2019). Pemasaran Melalui Media Sosial: Solusi Pemasaran Digital Bisnis Anda. Diakses tanggal 1 Maret 2021 di https://seoanaksholeh.com/marketing/pemasaran-melalui-media-sosial.

Prajarto, Y. A. N., Tania, S., \& Purwaningtyas, M. P. F. (2019). Preferensi Informasi dan Perilaku Bermedia Warganet di Akun Instagram Media Informasi Selebritas. Jurnal Ilmu Komunikasi, 16(2), 191-208.

Prensky, M. (2001). Digital Natives, Digital Immigrants Part 1. On the Horizon, 9(5), 1-6. https://doi.org/10.1108/10748120110424816.

Priyono, A. E., \& Hamid, U. (2014). Merancang Arah Baru Demokratisasi. Jakarta: Kepustakaan Populer Gramedia.

Rafiah, K. K., \& Kirana, D. H. (2019). Analisis Adopsi Media Sosial sebagai Sarana Pemasaran Digital bagi UMKM Makanan dan Minuman di Jatinangor. Jurnal Ekonomi \& Ekonomi Syariah, 2(1), 188-198.

Rahayu, N. (2018). 10 Manfaat Internet Marketing bagi Bisnis. Warta Ekonomi, 20 April. Diakses tanggal 10 Januari 2020 di https://www.wartaekonomi.co.id/read178295/10manfaat-internet-marketing-bagi-bisnis.

Rahmalia, N. (2021). Mengenal Reach, Cara Ukur Efektivitas Strategi Digital Marketing. Glints Blog, Marketing, 26 Februari. https://glints.com/id/lowongan/reachadalah/?utm_source=whatsapp\&utm_medium=addthis\#.YGWzdPkzbIV.

Rahulan, M., Troynikov, O., Watson, C., Janta, M., \& Senner, V. (2015). Consumer Behavior of Generational Cohorts for Compression Sportswear. Journal of Fashion Marketing and Management, 19(1), 87-104. https://doi.org/http://dx.doi.org/10.1108/JFMM-05-2013-0072.

Ramadhan, F. H. (2017). Pemanfaatan Media Sosial Instagram Akun @ Mr. Creampuff sebagai Promosi dalam Meningkatkan Penjualan. JOM FISIP, 4(2), 1-15.

Rizal, A. (2019). Demografi Pengguna Instagram di RI 2019, Paling Banyak Perempuan. 24 Desember 2019. Diakses tanggal 22 Juli 2020 di https://infokomputer.grid.id/read/121964120/demografi-pengguna-instagram-di-ri2019-paling-banyak-perempuan 
Rony, N. F., \& Panuju, R. (2018). Digital Media Hospital: Aplikasi Komunikasi Pemasaran Berbasiskan Daring. Jurnal Komunikasi Profesional, 2(2), 120-128.

Sawyer, S., \& Jarrahi, M. H. (2013). Sociotechnical Approaches to the Study of Information system. In A. Tucker \& H. Topi (eds). CRC Handbook of Computing. London: Chapman and Hall, Inc.

Schewe, C. D., Meredith, G. E., \& Noble, S. M. (2000). Defining moments-segmenting by cohorts. Marketing Management, 9(3), 48-53.

Setiawati, S. D., Fitriawati, D., Retnasary, M., \& Yelifa, I. R. Pesan Pemasaran Senjata untuk Membangun Digital Marketing. Syntax Literate: Jurnal Ilmiah Indonesia, 4(7), 131-151.

Siagian, A. O., Martiwi, R., \& Indra, N. (2020). Kemajuan Pemasaran Produk dalam Memanfaatkan Media Sosial di Era Digital. Jurnal Pemasaran Kompetitif, 3(3), 4451.

Simangunsong, E. (2018). Generation-Z Buying Behaviour in Indonesia: Opportunities for Retail Businesses. MIX: Jurnal Ilmiah Manajemen, 8(2), 243-253. https://doi.org/http://dx.doi.org/10.22441/mix.2018.v8i2.004 243

Smith, K. T. (2011). Digital marketing strategies that Millennials find appealing, motivating, or just annoying. Journal of Strategic marketing. 19(6), 489-499.

Soelistyowati, D. (2019). Partisipasi Warganet dalam Mengidentifikasi Komunikasi Intelektual Narasumber Politik Terkait Perkembangan Hasil Pemilu 2019. Wacana, 18(2), 234-245.

Sofyan, A., Ferdianto, E., Rahmawati, R., \& Aldi, R. K. (2019). Pengaruh Search Engine Optimization (SEO) Kata Kunci terhadap Pendapatan Toko Online. Politeknik Indonusa Surakarta. Indonusa Conference on Technology and Social Science 2019 (INCONTECSS), 16 November, 351-356.

Stone, M. D., \& Woodcock, N. D. (2014). Interactive, direct and digital marketing: A future that depends on better use of business intelligence. Journal of Research in Interactive Marketing. 8 (1), 4-17.

Strauss, W., \& Howe, N. (1991). Generations: The History of America's Future. New York: Quill William Morrow.

Suharso, P. (2019). Pemanfaatan Drone Emprit dalam Melihat Trend Perkembangan Bacaan Digital melalui Akun Twitter. Anuva, 3(4), 333-346.

Susilo, B. (2018). Pemasaran Digital: Segmentasi Demografi Pengguna Media Sosial di Kota Pontianak. Eksplora Informatika, 8(1), 69-79. https://doi.org/10.30864/eksplora.v8i1.163

Suzuki, K. (2007). Welcome to the World of "Netizens". Diakses tanggal 22 Juli 2020 di http://www.gsis.kumamoto-u.ac.jp/ksuzuki/resume/addresses/a30727.pdf.

Tatarina, W. A. W., \& Husna, J. (2017). Dampak Media Sosial Instagram @jaklib_cikini sebagai Media Promosi Perpustakaan Umum Daerah Provinsi DKI Jakarta Cikini. Jurnal Ilmu Perpustakaan, 6(1), 351-360. 
Widyananda, R. F. (2020). 10 Macam Media Sosial yang Paling Sering Digunakan oleh Orang Indonesia. Merdeka.com, 4 Juni. Diakses 23 Juli 2020 di https://www.merdeka.com/jatim/10-macam-media-sosial-yang-paling-seringdigunakan-oleh-orang-indonesia-kln.html.

Yasmin, A., Tasneem, S., \& Fatema, K. (2015). Effectiveness of Digital Marketing in the Challenging Age: An Empirical Study. International Journal of Management Science and Business Administration, 1(5), 69-80. 